\title{
Topologic and Geometric Structure of Spatial Relations in Latvian: an Experimental Analysis of RCC
}

\author{
Jurğis ŠĶILTERS ${ }^{1}$, Līga ZARIN̦A ${ }^{1}$, Eglè ŽILINSKAITE ${ }^{2}$, \\ Nora BĒRZIN,A ${ }^{1}$, Linda APSE ${ }^{1}$ \\ ${ }^{1}$ University of Latvia, Laboratory for Perceptual and Cognitive Systems at the Faculty of \\ Computing, Rainga blvd. 19, Riga, Latvia \\ ${ }^{2}$ Vilnius University, Institute for the Languages and Cultures of the Baltic, Faculty of Philology, \\ Universiteto str. 5, Vilnius, Lithuania

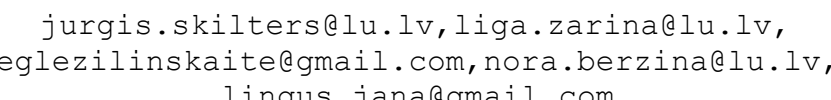

\begin{abstract}
In this study we experimentally test topological and geometric relations as encoded in Latvian. The task of the subject is to describe different combinations of two geometric objects presented in a randomized order. For the in-group experiment two circles - dark and light - were used according to the topological principles of Region Connection Calculus further extended with simple relational variables representing proximity, orientation, object size, and partial occlusion. The results show that both topological and geometric features determine the number of words used in the description of the respective relations and accuracy of the description. Further, we explored the most common words used for the description of general spatial relations and tested the differences associated with the experimental variables. It was concluded that topological and geometric relations matter in the linguistic representation of space but to a differing degree. Our results also indicate that spatial relations at the linguistic level are represented categorically and rarely encode fine-grained information.
\end{abstract}

Keywords: Region Connection Calculus, Experimental study, Spatial relations, Spatial language, Latvian language

\section{Theoretical framework}

Humans represent space relationally (with some very few metric principles) which is consequentially encoded in natural languages. Space is perceived by generating a holistic, finegrained and analogical representation. Once space is encoded in language a sequential and categorical representation is generated. In short, once the perceived space is represented linguistically fine-grained and metric relations are transformed into categorical relations, frames of reference are selected, and spatial description is ordered in a coherent way (Newcombe and Huttenlocher, 2000). 
Although there are several powerful formalisms of qualitative reasoning such as RCC, Egenhofer's approach, or Allen's interval algebra - all intuitively resemble the way humans understand space and time, there are very few experimental studies testing how well these formalisms fit into the psychological mechanisms of spatial or temporal processing (for some notable exceptions cp. (Knauff et al., 1997) or (Knauff, 1999), for a comprehensive overview of qualitative reasoning cp. (Forbus, 2018)).

Our primary goal was to test natural language interpretation on a set of robust topological relations. For this purpose, we used Region Connection Calculus (RCC), (Randell et al., 1992), (Cohn et al., 1997) extended with some geometric variables (orientation, proximity, size, occlusion). Both distance operations between objects and object size and shape have impact on the perception of the spatial relations (cp., e.g., (Kluth et al., 2017)). Another aspect of the current research was to explore what descriptions in natural language are induced in native language users by this extended set of RCC relations and further identify the most diverse and most unambiguous cases.

$\mathrm{RCC}$ is a robust topological language for expressing simple topological relations. RCC can be recursively defined in first-order logic starting from the relation of connectedness. In the current work RCC will be complemented with some geometric and functional operators (as defined in language $\mathrm{RCC}+\mathrm{F}$, Skilters et al., in prep; for previous studies on those functional or geometric extensions or operators cp. (Cohn et al., 1997), (Mani and Pustejovsky, 2012), (Della Penna et al., 2017), (Forbus et al, 2017), (Gerevini and Renz, 2002):

(I) Topological principles (RCC)

1. Connectedness $(C): C(x, y)$

2. Disconnectedness $(D C): D C(x, y) \equiv_{\text {def }} \neg C(x, y)$

3. Part $(P): P(x, y) \equiv_{\text {def }} \forall z[C(z, x) \rightarrow C(z, y)]$

4. Proper part $(P P): P P(x, y) \equiv_{\text {def }} P(x, y) \wedge \neg P(y, x)$

5. Overlap $(O): O(x, y) \equiv_{d e f} \exists z[P(z, x) \wedge P(z, y)]$

6. External connectedness $(E C): E C(x, y) \equiv_{\text {def }} C(x, y) \wedge \neg O(x, y)$

7. Partial overlap $(P O): P O(x, y) \equiv_{\text {def }} O(x, y) \wedge \neg P(x, y) \wedge \neg P(y, x)$

8. Equality $(E Q): E Q(x, y) \equiv_{\text {def }} P(x, y) \wedge P(y, x)$

9. Discreteness $(D R): D R(x, y) \equiv_{\operatorname{def}} \neg O(x, y)$

10. Tangential proper part $(T P P): T P P(x, y) \equiv_{d e f}$ $P P(x, y) \wedge \exists z[E C(z, x) \wedge E C(z, y)]$

11. Non-tangential proper part $(N T P P): \operatorname{NTPP}(x, y) \equiv_{\text {def }}$ $P P(x, y) \wedge \neg \exists z[E C(z, x) \wedge E C(z, y)]$

(II) Geometric principles

12. Convex hull (Cohn et al., 1997, 287ff.):

12.1. convex inside: $\operatorname{inside}(x, y) \equiv_{\text {def }} D R(x, y) \wedge P(x, \operatorname{conv}(y))$

12.2. partially convex inside: $p_{-}$inside $(x, y) \equiv_{\text {def }} D R(x, y) \wedge P O(x$, $\operatorname{conv}(y))$; 
12.3. convexity outside regions: outside $(x, y) \equiv_{\operatorname{def}} \operatorname{DR}(x, \operatorname{conv}(y))$

13. Orientation (ORIENT) (Mani \& Pustejovsky, 2012, 32; for a more exact way of expressing orientation primitives cp. Della Penna, Magazzeni, \& Orefice, 2017)

13.1. $\operatorname{UNDER}(x, y)$,

13.2. $\operatorname{OVER}(x, y)$,

13.3. TO_THE_RIGHT_OF $(x, y), T O_{-} T H E_{-} L E F T \_O F(x, y)$

13.4. IN_FRONT_OF $(x, y), B E H I N D \_O F(x, y)$

13.5. NEXT_TO $(x, y)$

14. Distance (DIST) (Mani \& Pustejovsky, 2012, 33, for an approach providing a more precise distance operation compatible with the current one: Della Penna et al., 2017; for approach linking topology and distance information cp. Shen et al., 2018)

14.1. $\operatorname{NEAR}(x, y)$

14.2. $F A R(x, y)$

(III) Some additional geometric features and transformations (cp. also (Forbus et al, 2017))

15. Curvature

15.1. $\operatorname{STRAIGHT}(x)$

15.2. $\operatorname{CURVED}(x)$

16. Axial information

16.1. VERTICAL $(x)$

16.2. HORIZONTAL $(x)$

16.3. OBLIQUE $(x)$

16.4. PARALLEL $(x, y)$

16.5. PERPENDICULAR $(x, y)$

16.6. $\operatorname{COLLINEAR}(x, y)$

(IV) Functional relations (not applied to this study):

17. Support: an object $x$ is downward and $y$ is upward $E C^{S}\left(x^{S \rightarrow}, y^{\rightarrow S}\right)$

18. Locational control: once $y$ is moved $x$ is moved as well $\operatorname{LocC}(x, y)$.

(V) Two additional operators that are not included in $\mathrm{RCC}+\mathrm{F}$ but are important for our study:

19. Partial occlusion: object $x$ partially occludes object $y$ $\operatorname{POccl}(x, y) \equiv_{\text {def }} O(x, y) \wedge \neg P(x, y) \wedge \neg P(y, x) \wedge \operatorname{Occl}(x, y)$ or shorter (according to the definition of $P O): \operatorname{POccl}(x, y) \equiv_{\text {def }} P O(x, y) \wedge \operatorname{Occl}(x, y)$

20. Size: object $x$ is larger than $y$

$\operatorname{LARGER\_ THAN}(x, y)$ where LARGER_THAN is asymmetric and transitive (for a model combining topological and size information cp. (Gerevini and Renz, 2002)). 
In the current study on spatial relations there are several major approaches used for representation of spatial relations. What follows is a brief overview of some main formalisms to show how $\mathrm{RCC}+\mathrm{F}$ is relevant for the purposes of the current work.

\section{Alternative approaches: Vector systems}

Another approach in formalizing spatial relations is use of vector maps (for a semantic framework cp. (Zwarts, 1997), (Zwarts and Winter, 2000)). Although vector systems are more intuitive for formalizing directional and motional spatial information, static locational relations can also be modeled using vectors (assuming that regions are sets of vectors). The principal idea behind vector semantics is that spatial information (prepositional in particular) can be modeled using a set of vectors representing the position of the figure object in relation to ground. E.g., modifiers are mappings to subsets of this set. PPs (prepositional phrases) are typically modified in terms of distance ("a couple of meters behind the house") or direction ("to the right above the chair"). By default, vectors incorporate distance and direction. Vector space $\mathbf{V}$ is a set of vectors with the same origin and can be defined over real numbers, closed under addition (for every pair of vectors $\mathbf{v}, \mathbf{w} \in \mathbf{V}$ there is one and only one vector sum of $\mathbf{v}$ and $\mathbf{w}$, i.e., $\mathbf{v}+\mathbf{w} \in \mathbf{V}$ ) and scalar multiplication (for every vector $\mathbf{v}$ such that $\mathbf{v} \in \mathbf{V}$ and $s \in R$ there is one and only one $s \mathbf{v} \in \mathbf{V}$, i.e., the scalar product of $\mathbf{v}$ by scalar s (Zwarts, $1997,66)$. This means that vector space ontology is a quadruple $\langle\mathbf{V}, 0,+, \cdot\rangle$ such that $0 \in$ $\mathbf{V}$ (a zero vector) and the functions corresponding to addition and multiplication apply: $+:(\mathbf{V} \times \mathbf{V}) \rightarrow \mathbf{V}$ and $\cdot:(\mathrm{R} \times \mathbf{V}) \rightarrow \mathbf{V}$. Additionally, a scalar product over the vector space $\mathbf{V}$ is a function $f:(\mathbf{V} \times \mathbf{V}) \rightarrow \mathrm{R}$ (Zwarts and Winter, 2000).

To use vectors, in addition to $\mathbf{V}$, the set of objects $E$ and another set of vectors $\mathbf{S}$ have to be added such that $\mathbf{S}$ provides vectors pointing from any two points in both directions. Additionally, a relation $l o c$ is used to determine the relationship between the set of objects $\mathrm{E}$ and vectors $\mathbf{S}$. If $x$ and $y$ are any objects and $\mathbf{v}$ and $\mathbf{w}$ are vectors, then (a) $\operatorname{loc}(x, y)$, i.e., $x=y$; (b) $\operatorname{loc}(\mathbf{v}, x)$, i.e., the beginning point is located at object $x$; (c) $\operatorname{loc}(y, \mathbf{w})$, i.e., $\mathbf{w}$ ends at an object $y$; (d) $\operatorname{loc}(\mathbf{w}, \mathbf{v})$, i.e., the endpoint of $\mathbf{v}$ starts $\mathbf{w}$ (Zwarts, 1997, 67). Accordingly, prepositional information can be modeled as $\llbracket$ in $N P \rrbracket=\{\mathbf{v} \in$ space $(\llbracket N P \rrbracket) \mid \mathbf{v}$ inward to $\llbracket N P \rrbracket\}$ (Zwarts, 1997, 70). Modifiers as $\llbracket[P P \operatorname{Mod} P P] \rrbracket_{M}=\left\{\mathbf{v} \in \llbracket P P \rrbracket_{M} \mid \ldots \mathbf{v} \ldots\right\}$, e.g., $\llbracket$ five centimeter $P P \rrbracket_{M}=\{\mathbf{v} \in \llbracket P P \rrbracket|| \mathbf{v} \mid$ $=5 \mathrm{~cm}\}\left(\right.$ Zwarts, 1997, 75) ${ }^{1}$.

To sum up, vector systems have advantages in representing directional and motion-related information but for our purposes to analyse core topological and geometrical relations in static settings this approach substantially increases the formal complexity. But it is worth noting that vector systems are compatible with our approach except that we assume regions instead of point sets that is typically the case in vector systems.

\footnotetext{
${ }^{1}$ Where NP is a Noun Phrase and PP is a Prepositional Phrase
} 


\section{Locatives as localiser and modaliser structures}

Kracht (2002) has proposed another influential framework applying geometric properties to a model-theoretic analysis. According to Kracht, locative expressions consist of location (defining elements are localisers referring to configuration) and a type of movement in respect to location (modalisers referring to the mode of configuration). Modalisers and localisers typically form morphological units represented as cases or adpositions. Configurations are relative positions of objects to one another and do not per se include directional and dynamic information. 'Mode' represents object movement with respect to the above-mentioned configuration. Modes, according to Kracht (2002, 159), can be either static ("object remains static in the configuration during the event time", e.g., in the house), cofinal ("object moves into the configuration during the event time"; e.g., into the store), coinitial ("object moves from the configuration", e.g., out of the concert hall), transitory ("object moves in and again out of the configuration"; through the tunnel / park), approximative ("object approaches a configuration" (towards the island)). The structure of a locative expression therefore is:

\section{$[M[L D P]]$}

where $M$ is a modaliser, $L-$ a localizer (referring to a configuration), $D P-$ a determining phrase; and $M+L$ is a unit (adposition or case) (Kracht, 2002, 159).

A space-time integrating ontology proposed by Kracht (176f.) consists of the following types: $e$ (objects), $i$ (time points), $p$ (spatial points), $v$ (events; a subtype of $e$ ), $t$ (truth values), $r$ (regions; a subtype of spatial points), $j$ (intervals; a subtype of time points). According to the analysis of Kracht, a part of the sentence 'The cat appeared from under the table' would be represented as [from[under[the table]]], where the NP is ground (landmark) and 'under' is a localizer and 'from' - a modaliser (denoting the mode). $[M[L D P]]$ where $[L D P]$ is a Location Phrase $(L P)$ and the whole $[M[L D P]]$ a Mode Phrase $(M P)$ (cp. 185). In our terminology, the whole $L P$ describes ground (Kracht clarifies that semantically $D P$ are objects whereas $[L D P]$ are parametrized neighbourhoods and $[M[L D P]]$ a set of events; p. 202). $L P$ and localizers encode canonical local relations. Kracht provides a complex and extensional definition of $L P$, the core idea being: If $R$ is the set of regions then a local relation is a subset of $R \times R$ or to put it in a slightly modified way: localizers are functions from regions to neighbourhoods, i.e., subsets of regions. Further, localizers are time dependent (p. 187).

The analysis of modalisers refers to the mode that can be either dynamic / directional or static. In case of a dynamic mode (Kracht, 2002, 192), time intervals $I$ and $J$ are ordered $J \subseteq I$. $J$ properly begins $I$, i.e., $\operatorname{pbeg}^{\prime}(J, I)$ if $J \neq I$ and for all $s \in I$, there is a $t \in J$ such that $t \leq s$. In contrast, $J$ properly ends $I$ (pend $(J, I))$ if $J \neq I$ and for all $s \in I$, there is a $t \in J$ such that $s \leq t$.

The verbs in locatives (Kracht, 2002, 202) can either (a) refer to the whole $[M[L D P]],(\mathrm{b})$ to $[L D P]$, or (c) $D P$ only.

Although Kracht's approach provides a coherent model- theoretic analysis, it increases formal complexity that is necessary for analysis natural language semantics analysis but exceeds the basic structures necessary for topological and geometric qualitative reasoning framework as in case of our approach. However, except some details Kracht's and our formalisms are compatible. 
Axial parts

Another paradigm that can be used for combining regions, point-sets or vectors is axial parts. According to Svenonius (2006) there are regions, point-sets or vectorspaces that can be described based on specific parts of ground-objects. Instead of concrete object parts, Axial Parts denote areas in virtue of specific parts of the ground object as in 'There was a kangaroo in front of the car' while in 'There was a kangaroo on the front of the car' it means that a specific part of the object, i.e., car (and therefore is not an axial part, a distinct category, but a noun). An important consequence from Svenonius' approach is that the ground areas are positioned at the end of the sentence (even preceded by different modifiers), whereas the figure objects come before the ground (i.e., in the initial part of the sentence).

All three approaches are at least partially compatible with our study: orientation, direction, and distance between figure and ground objects that are crucial in vector systems, locative, direction, and modifier structures (as in Kracht's approach), object parts (as in Svenonius's theory). However, our approach provides a simpler, topologically more direct way of expressing relations between spatial objects without increasing formal complexity but at the same time providing sufficiently rich system for qualitative spatial reasoning. The proposed system can be further improved e.g., by extending it with the underlying model-theory.

\section{RCC+F, size, distance, occlusion as the framework of modelling independent variables}

Apart from vector systems, two basic approaches in formalizing spatial relation is either to assume that spatial objects are (or occupy) point sets (e.g., (Egenhofer and Franzosa, 1991)) or that spatial objects are (or occupy) regions (Randell et al.,1992). Although there are several possibilities to combine both approaches, the latter seems to be closer to the way humans perceive spatial relations. Region-based approach is also closer to the everyday common-sense reasoning about physical world (the naïve worldview; cp. (Hayes, 1985), (Aurnague and Vieu, 1993), (Vieu, 1997), (Davis et al., 2017)) and therefore is a feasible framework for AI systems.

Because of its robustness and flexibility, versions of RCC (and its extensions) are frequently used in cognitive science, qualitative reasoning, and computational linguistics (e.g., for the purpose of semantic annotation) (e.g., (Mani and Pustejovsky, 2012), (Pustejovsky and Lee, 2017)), development of visualization software (Forbus et al., 2017), domain independent visualizations in human-computer interaction (Della Penna et al., 2017), polysemy representation (Rodrigues et al., 2017), linking GIS and natural language (Vasardani et al., 2017), (Chen et al., 2017), theoretical enrichments of qualitative spatial reasoning by integrating algebraic and relational information (Stell, 2001), (Düntsch et al., 2001), and implementation in large-scale distributed spatiotemporal reasoning over qualitative spatio-temporal datasets (Mantle et al., 2019).

However, there are very few empirical studies testing the perception of RCCbased topological relations (e.g., (Knauff et al., 1997) and (Rodrigues et al., 2017 and several studies by Klippel and his colleagues (for an overview see (Klippel et al., 2013)) 
who have focused on geospatial and large-scale spatial reasoning and showing the impact of size and semantic domain). In an initial study Knauff and colleagues asked a small set of subjects $(n=20)$ to group different spatial configurations with respect to their similarity and to describe their groupings (Knauff et al., 1997). They compared RCC and Egenhofer's approach (Egenhofer and Franzosa, 1991) and found that both are cognitively plausible and contain a large number of topological descriptions (i.e., topological descriptions seem to be dominating over other types of descriptions and RCC-8 corresponds to an optimal level of conceptualizing of spatial relations).

Klippel et al. (2013) provide a somewhat less conclusive set of results (if compared to Knauff et al. (1997) regarding their Egenhofer-Cohn hypothesis which states that topological theories are underlying spatial cognition. Klippel et al. argue that linking formal / qualitative and cognitive representations requires a more complex set of interrelations. Their argument consists of several core statements: (a) some topological relations are more crucial than the others and not all topological relations or equivalence classes have their cognitive counterparts (b) size and semantic domain have impact on the resulting perception of spatial relations within RCC (eventually less than 8 relations are cognitively valid; cp. also (Clementini et al., 1993)); (c) topology is not the only aspect that is used for structuring spatial information; geometry (e.g., directionality, size) also matters and in a much more complex way; (d) semantic domains have impact on the perception of topological relations; (e) static of dynamic objects have significant impacts on the perception of their topology.

To sum up so far, we agree with Klippel et al. (2013) that cognitive representation of space is more complex, weighted and context dependent than just a straightforward mapping from topology and geometry to cognitive representation.

We agree with (Lovett and Franconeri, 2017) and (Roth and Franconeri, 2012) that touching, overlapping and containing are most crucial relations. However, we also assume that these three relations can be used in a variety of different ways (the reason why we have extended the initial set of RCC relations).

In our approach, we adopt a widely accepted and both empirically and theoretically confirmed view that once an object (Figure / Central object (F)) is located or searched for, a reference object (Ground, G) is involved to establish the exact place of F. (For initial work in linguistics cp. (Talmy, 1975); for a recent evidence that the asymmetric figure and ground distinction operates also in vision and visual attention $\mathrm{cp}$. (Roth, and Franconeri, 2012), (Yuan et al., 2016).) It might also be the case that figure objects are perceptually processed earlier than the ground, therefore providing another explanation of the figure-ground asymmetry effect (Lester et al., 2009).

Once the question referring to object $(F)$ in a particular visual configuration is asked, the answer is the relation that binds $\mathrm{F}$ and $\mathrm{G}$ or, in other words: when presenting stimuli with $\boldsymbol{R}(F, G): \boldsymbol{R} \in \mathrm{RCC}+\mathrm{F}$ accompanying question $(Q)$ is

$$
Q \text { : Where is } F \text { ? }
$$

Then answer $(Q)$ is contained in the structure

$$
A: R(F, G) \text {, }
$$

where $R$ is any spatial relation that human observer assigns to the stimuli configuration.

In total, the following experimental situation can be constructed: Spatial configuration as contained in stimuli: $\boldsymbol{R}(F, G): \boldsymbol{R} \in \mathrm{RCC}+\mathrm{F}$

$$
Q: \text { Where is } F \text { ? }
$$

$$
\text { A: } R(F, G)
$$


Although we assume (and agree with Coventry and Garrod, 2004; Vandeloise, 1991) that geometric relations are functionally constrained, we do not go as far as to say that functional relations replace geometrical relations. We agree with Landau (2017) that there seem to be geometrical relations that complement functional relations.

In particularly we agree with Kluth et al., (2017) that object relative size and distance can shape the perception of object relations. This is also supported by evidence that size perception starts operating relatively early and human perceptual system is rather sensitive to size information (Choo and Franconeri, 2010).

Our framework also supports the idea that spatial relations in general and topological relations in particular are encoded categorically (Lovett and Franconeri, 2017; Yuan et al., 2016): instead of using metric or continuous features, humans tend to segment space into discrete categories that are remembered and compared easier than metric categories. A consequence of this view is that human perception is more robust and is encoded in language in a restricted way. Metric information is less important, more difficult (e.g., slower) and less precise to use than categorical information. Categorical coding is more efficient and reliable (for different other kinds of evidence cp. (Amir at al., 2014), arguing that basic shape information is primary in respect to metric information (Kosslyn et al., 1977), providing evidence that size information is primarily used in a categorical manner).

Further, we also agree that spatial relations are foundational to other type of knowledge (e.g., abstract, non-spatial, or temporal). According to several prominent studies, spatial knowledge shapes the way we structure temporal knowledge (Gentner et al., 2002; Jamrozik and Gentner, 2015). Although there are some more cautious results (cp. Kranjec et al., (2010)) stating that spatial and temporal systems are distinct and spatial schemas are not necessary for temporal reasoning, even these results indicate that spatial knowledge can shape the temporal thought.

Finally, although spatial relations are primary with respect to other (e.g., temporal or abstract) domains, this does not mean that non-linguistic spatial relations are independent from their linguistic representation; e.g., as shown by Holmes et al. (2017), linguistic representation of support constrains non-linguistic spatial knowledge. Further, we might also assume that spatial language and non-linguistic spatial knowledge are systematically aligned in different language communities and populations (Haun et al., 2011) although the strength of relatedness seems to vary and be stronger in linguistically closer populations (which is the case of Latvian and Lithuanian, cp. (Žilinskaitè-Šinkūnienè et al., 2019)).

\section{Overall Design / General design}

\subsection{Method}

We have used a modified production test which is well established for both geometric (Logan, and Sadler, 1996) and functional (Coventry et al., 2001) relations, and has been used in other areas, including developmental analysis of spatial relations 
(Munnich and Landau (2010); for a general overview and context: Carlson and Hill (2007); varied and specific applications of production task see also Taylor and Tversky (1996), Plumert et al. (1995)).

Our independent variables are $\mathrm{RCC}+\mathrm{F}$ (i.e, $\mathrm{RCC}$ extended with simple proximity information, orientation), and in some stimuli - size and partial occlusion (in the latter sense it is not the case of RCC).

\subsection{Design and procedure}

The experimental data were obtained from a questionnaire that included 31 stimuli presented separately in a random order. Each stimulus contained 2 circles (light and dark) that were located in different topological and geometrical configurations. The task was to describe the location of the dark circle in relation to the light circle. The question: "Where is the dark circle?" had to be answered in a partially open-ended production task. The place where answer had to be inserted was introduced by words "The dark circle" therefore inducing the answers containing the spatial relation between the Figure (the dark circle) and the Ground (the reference object - the light circle). (We were not able to use a version of restricted production task where the relation only could be inserted since Latvian has a rich system of cases and coordination between prepositions and cases.)

The questionnaire started with a brief introduction of the task and the instruction "please, define the location of the dark circle in relation to the white one". After the experimental task some demographic questions were asked. Part of the data was collected in a paper-pencil form. The rest was collected through online survey created with the QuestionPro tool. The descriptive statistics and statistical tests (Chi-square test, t-test, paired sample t-test, Mann-Whitney U test, Wilcoxon Signed Ranks test, regression analysis (binomial logistic, ordinal logistic, linear), Spearman's correlation) were conducted by software SPSS Statistics 22.

\subsection{Stimuli}

We used the following types of independent variables: RCC relations, partial occlusion, orientation, proximity and size. Every category contained several subtypes and were combined with each other according to the principles summarized in Table 1. For some types we did not use all possible combinations to keep the total number of stimuli sufficiently small and avoid fatigue effects in subjects. We also assumed that certain effects of some independent variables might be similar and can be explored in additional studies, if necessary, in future. At the same time, we assumed that the tendencies connected with the independent variables could be detected through multidimensional statistical analysis. 
Table 1. The stimuli used in the study, summarized according to independent variables

\begin{tabular}{|c|c|c|c|c|c|}
\hline & Orientation & & & & \\
\hline $\begin{array}{l}\text { RCC, } \\
\text { proximity }\end{array}$ & $\begin{array}{l}\text { TO THE } \\
\text { RIGHT (E) }\end{array}$ & OVER (N) & $\begin{array}{l}\text { TO THE LEFT } \\
\text { (W) }\end{array}$ & UNDER (S) & $\begin{array}{l}\text { OBLIQUE (NE, SE, SW, } \\
\text { NW) }\end{array}$ \\
\hline \multirow{3}{*}{$\begin{array}{l}\text { DC } \\
\text { FAR }\end{array}$} & 1 DC_Far_E & 2 DC_Far_N & 3 DC_Far_W & 4 DC_Far_S & 17 DC_Far_NE \\
\hline & & 0 & & 0 & 0 \\
\hline & 00 & 0 & 00 & 0 & 0 \\
\hline \multirow[t]{2}{*}{$\begin{array}{l}\text { DC } \\
\text { NEAR }\end{array}$} & & & 7 DC_Near_W & 8 DC_Near_S & 18 DC_Near_SE \\
\hline & 00 & $\begin{array}{l}\bigcirc \\
0\end{array}$ & 00 & $\begin{array}{l}0 \\
0\end{array}$ & $\mathrm{O}_{0}$ \\
\hline \multirow[t]{2}{*}{ EC } & 9EC_E & $10 \mathrm{EC} \_\mathrm{N}$ & $11 \mathrm{EC} \_\mathrm{W}$ & $12 \mathrm{EC} \_\mathrm{S}$ & 19 EC_SW \\
\hline & $\infty$ & 8 & $\infty$ & 8 & $\rho$ \\
\hline \multirow[t]{2}{*}{ PO } & 13 PO_E & $14 \mathrm{PO} \_\mathrm{N}$ & $15 \mathrm{PO}_{-} \mathrm{W}$ & $16 \mathrm{PO}_{-} \mathrm{S}$ & $20 \mathrm{PO} \_\mathrm{NW}$ \\
\hline & $\infty$ & 8 & $\infty$ & 8 & $\theta$ \\
\hline $\begin{array}{l}\mathrm{RCC}, \\
\text { orientation }\end{array}$ & $\begin{array}{l}\text { NTPP } \\
\text { CENTRAL }\end{array}$ & $\begin{array}{l}\text { NTPP } \\
\text { OBLIQUE }\end{array}$ & $\begin{array}{l}\text { NTPPi } \\
\text { OBLIQUE }\end{array}$ & $\begin{array}{l}\text { TPP } \\
\text { OBLIQUE }\end{array}$ & $\begin{array}{l}\text { TPPi } \\
\text { OBLIQUE }\end{array}$ \\
\hline \multirow{2}{*}{$\begin{array}{l}\text { Size: } \\
\text { LARGE } \\
\text { SMALL }\end{array}$} & 21 NTPP_C & 22 NTPP_NW & 24 NTPPi_NW & 26 TPP_SE & 29 TPPi_SE \\
\hline & \multicolumn{4}{|l|}{ Orientation } & \\
\hline $\begin{array}{l}\text { Partial } \\
\text { occlusion }\end{array}$ & $\begin{array}{l}\text { TO THE } \\
\text { RIGHT }\end{array}$ & OVER & TO THE LEFT & UNDER & \\
\hline \multirow{2}{*}{$\begin{array}{l}\text { Figure- } \\
\text { object } \\
\text { occludes }\end{array}$} & 31 F_OCC_E & 32 F_OCC_N & & $34 \mathrm{~F} \_\mathrm{OCC} \_\mathrm{S}$ & \\
\hline & $\infty$ & 8 & & 8 & \\
\hline \multirow{2}{*}{$\begin{array}{l}\text { Ground- } \\
\text { object } \\
\text { occludes }\end{array}$} & & $36 \mathrm{G} \_\mathrm{OCC} \_\mathrm{N}$ & 37 G_OCC_W & $38 \mathrm{G} \_\mathrm{OCC} \_\mathrm{S}$ & \\
\hline & & 8 & $\infty$ & 8 & \\
\hline
\end{tabular}

\subsection{Participants}

45 participants filled in the questionnaire in paper-and-pencil task (further: ptask) while 60 participants participated in an online survey (further: e-task). The number of male and female participants was balanced for the e-task $-52 \%$ female and $48 \%$ male with more male participants for the p-task $-30 \%$ female and $70 \%$ male. 
Almost all participants were native speakers of Latvian (in both tasks 3 participants indicated Russian as their native language) with English as the second $(91 \%)$ and Russian as the third $(72 \%)$ best known language.

Most of the participants who filled in the e-task had university education (75\%), while $37 \%$ of the participants in p-task were with university education and $11 \%$ with secondary school education. Humanities/social sciences were the most frequent fields of education $(60 \%)$ with the e-task participants. Most of the participants in the p-task were from the fields of exact sciences; humanities and social sciences were represented by $34 \%$ participants. Also, we had to take into account the number of participants with secondary school education who filled in the paper task, because they could not provide information about field of education.

The age distribution of participants was similar in both tasks (p-task/e-task) younger than $25: 41 \% / 30 \% ; 25-34: 23 \% / 27 \%$; 35-44: $16 \% / 23 \%$; 45-54: $9 \% / 8 \%$ and older than 55: $11 \% / 12 \%$ ).

Demographic part also included questions regarding occupation and hobbies and the place where they had lived for the most part of their lives. The electronic task ended with the question about right-/left-handedness (92\%/8\%). Median time for completing the electronic task was $\sim 14$ minutes.

\section{Results}

The received answers were coded by grouping all words used in the descriptions into several categories. The general categories and their subcategories are listed in Table 2.

Table 2. Categories for coding the words used in the stimuli descriptions

\begin{tabular}{|c|c|c|}
\hline Category & Subcategory & Examples (example in Latvian) \\
\hline Dark circle (Figure object) & $\begin{array}{l}\text { (a) Location, (b) appearance, (c) } \\
\text { size, (d) object, (e) object part, } \\
\text { (f) pronoun }\end{array}$ & $\begin{array}{l}\text { (a) Upper (augšéjais), (b) grey } \\
\text { (pelēkais), (c) large (lielais), (d) } \\
\text { circle (aplis), (e) side (mala), (f) } \\
\text { which (kuršs) }\end{array}$ \\
\hline Reference (Ground) object & $\begin{array}{l}\text { (a) Location, (b) appearance, (c) } \\
\text { size, (d) object, (e) object part, } \\
\text { (f) pronoun, (g) background }\end{array}$ & $\begin{array}{l}\text { (a) First (priekšéjais), (b) white } \\
\text { (baltais), (c) small (mazais), (d) } \\
\text { circle (aplis), (e) side (mala), (f) } \\
\text { which }(\text { kurš), (g) page (lapa) }\end{array}$ \\
\hline $\begin{array}{l}\text { Both circles - reference (Ground) } \\
\text { object and the dark circle }\end{array}$ & (a) Object part, (b) pronoun & (a) point (punkts), (b) they (tie) \\
\hline Verb & & $\begin{array}{l}\text { Is }(\text { ir), located (atrodas), oriented } \\
\text { (orientēts), placed (novietots) etc. }\end{array}$ \\
\hline $\begin{array}{l}\text { TOPverb - verbs specifying } \\
\text { topological relations in relatively } \\
\text { precise topological terms (in } \\
\text { present study they are called } \\
\text { 'topological verbs' or TOPverbs) }\end{array}$ & & $\begin{array}{l}\text { Split (škelt), cross (krustot) } \\
\text { overlap (pārklāt), combine } \\
\text { (savienot), connect (saskarties), } \\
\text { touch (piekļauties) etc. }\end{array}$ \\
\hline Prepositions and connectives & (a) Prepositions, (b) connectives & (a) From (no), (b) and (un) \\
\hline Adverbs & & $\begin{array}{l}\text { Almost (gandrīz), partly (daļejii), a } \\
\text { bit (mazliet) etc. }\end{array}$ \\
\hline
\end{tabular}




\begin{tabular}{|c|c|c|}
\hline Direction & $\begin{array}{l}\text { (a) Cardinal directions, (b) } \\
\text { geometric directions }\end{array}$ & $\begin{array}{l}\text { (a) North (ziemeļi), (b) horizontal } \\
\text { (horizontāli) }\end{array}$ \\
\hline Distance & $\begin{array}{l}\text { (a) Relative distance, (b) size of } \\
\text { distance }\end{array}$ & (a) Closer (tuvāk), (b)small (mazs) \\
\hline Numbers & & $\begin{array}{l}1 / 4,4,30 \text {, at } 19 \text { o'clock (plkst.. 19) } \\
\text { etc. }\end{array}$ \\
\hline Measurements & $\begin{array}{l}\text { (a) Units of measurements, (b) } \\
\text { object as measure, (c) geometric } \\
\text { measures, (d) what is measured }\end{array}$ & $\begin{array}{l}\text { (a) Percentages (procenti), (b) } \\
\text { piece (gabals), (c) angle (lenkisis), } \\
\text { (d) distance (attālums) }\end{array}$ \\
\hline Localization prepositions & $\begin{array}{l}\text { Left, right, over, above, up, on, } \\
\text { under, below, down, behind, } \\
\text { inside, next to, in front of, in the } \\
\text { middle, in the center, between, } \\
\text { around }\end{array}$ & $\begin{array}{l}\text { E.g., inside, in (iekšāa, iekšs, } \\
\text { iekšpusēe, iekšīenē, ietvaros etc.) }\end{array}$ \\
\hline Misc. & & $\begin{array}{l}\text { Traffic-light (luksofors), target } \\
\text { (mērksis), olympic ring } \\
\text { (olimpiskais aplis) etc. }\end{array}$ \\
\hline
\end{tabular}

We also introduced several additional variables listed in Table 3 below.

Table 3. Additionally introduced categories for coding the words used in stimuli descriptions

\begin{tabular}{|c|c|}
\hline Additional variables & Examples (example in Latvian) \\
\hline Comparison form & $\begin{array}{l}\text { Smaller (mazākais), lower } \\
(z e m a \bar{k})\end{array}$ \\
\hline Locative_Object & In the circle (aplī) \\
\hline Locative_Localization words in locative & In the middle (vidiu) \\
\hline Generalization of object part & $\begin{array}{l}\text { Side (mala), part (daļa), half } \\
\text { (puse), corner (stūris) }\end{array}$ \\
\hline $\begin{array}{l}\text { Word count of the description - amount of words used for the } \\
\text { description }\end{array}$ & $\begin{array}{l}\text { To the right }(\underline{P a \text { labi }})-2 \\
\text { Next to the light circle }(\underline{\text { Blakus }} \\
\text { gaišajam aplim })-3\end{array}$ \\
\hline $\begin{array}{l}\text { Accuracy of the description of the Figure's location - measure was } \\
\text { determined according to the granularity of the information provided } \\
\text { to describe where the Figure is situated. (The detailed criteria are } \\
\text { given in: Zilinskaite et al., 2019) }\end{array}$ & $\begin{array}{l}\text { To the right }(\underline{P a \text { labi }})-1 \\
\text { To the right, next to the light } \\
\text { circle }(\underline{P a \text { labi, }} \underline{\text { blakus gaišajam }} \\
\underline{\text { aplim }})-2\end{array}$ \\
\hline
\end{tabular}

The categories, localization preposition subcategories (Table 2) and additional variables (Table 3) were analysed as the dependent variables according to their frequency and variety corresponding to each configuration (Table 1). The summary of relative frequencies is summarized in Table 4 and Table 6 . (frequencies below 5\% are not included.) Each relative frequency (\%) reflects the amount of answers where words belonging to the particular category had been used. Frequencies differ within each category if the stimuli are compared. By the Chi-square test the differences over all stimuli set in each coded category were tested and the significant ones $(\alpha=0.05)$ are marked by blue and red colours. 
Table 4.1 Frequencies of the words used in the stimuli (Table 1) descriptions according the coded categories (Table 2 and Table 3), \%

\begin{tabular}{|c|c|c|c|c|c|c|c|c|c|c|c|c|c|c|c|}
\hline \multicolumn{5}{|c|}{ Right (E) } & \multicolumn{5}{|c|}{ Left (W) } & \multicolumn{6}{|c|}{ Over (N) } \\
\hline 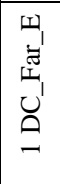 & 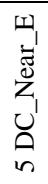 & $\begin{array}{l}\text { 피 } \\
\text { U } \\
\text { I }\end{array}$ & $\begin{array}{l}\stackrel{1}{\prime} \\
0 \\
\stackrel{2}{n} \\
\end{array}$ & 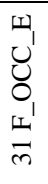 & $\begin{array}{c}3 \\
3 \\
w_{1}^{\prime} \\
w_{1}^{\prime} \\
0^{1} \\
m\end{array}$ & 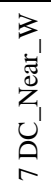 & $\begin{array}{l}3 \\
U^{\prime} \\
= \\
=\end{array}$ & $\begin{array}{l}3 \\
0 \\
0 \\
n \\
n\end{array}$ & $\begin{array}{l}3 \\
3 \\
0 \\
0 \\
0 \\
0 \\
m\end{array}$ & 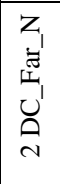 & $\begin{array}{l}z_{1} \\
\vec{J}^{\prime} \\
z_{1} \\
u_{0}^{\prime} \\
0\end{array}$ & $\begin{array}{l}Z_{1} \\
U_{1} \\
0 \\
0\end{array}$ & $\begin{array}{l}z_{1} \\
o^{\prime} \\
\vdots \\
\pm\end{array}$ & $\begin{array}{l}Z_{1} \\
u^{\prime} \\
\circlearrowright_{1} \\
\text { I } \\
\text { त }\end{array}$ & 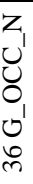 \\
\hline
\end{tabular}

\begin{tabular}{|c|c|c|c|c|c|c|c|c|c|c|c|c|c|c|c|c|}
\hline \multicolumn{17}{|l|}{ a) } \\
\hline \multirow[t]{2}{*}{ Dark (Figure) circle } & \multirow[b]{2}{*}{10} & \multirow[b]{2}{*}{10} & \multirow[b]{2}{*}{12} & \multirow[b]{2}{*}{14} & \multirow[b]{2}{*}{10} & \multirow[b]{2}{*}{11} & \multirow[b]{2}{*}{12} & \multirow[b]{2}{*}{11} & \multirow[b]{2}{*}{14} & \multirow[b]{2}{*}{20} & \multirow[b]{2}{*}{18} & \multirow[b]{2}{*}{20} & \multirow[b]{2}{*}{20} & \multirow[b]{2}{*}{23} & \multirow[b]{2}{*}{19} & \multirow[b]{2}{*}{26} \\
\hline & & & & & & & & & & & & & & & & \\
\hline \begin{tabular}{|l|} 
Reference \\
(Ground) object
\end{tabular} & 50 & 51 & 54 & 60 & 61 & 49 & 51 & 54 & 62 & 66 & 61 & 60 & 62 & 70 & 69 & 67 \\
\hline \begin{tabular}{|l|}
$\begin{array}{l}\text { Both circles } \\
\text { (common parts) }\end{array}$ \\
\end{tabular} & & & 11 & 6 & & & & 13 & 8 & & & & 14 & 9 & & \\
\hline \multicolumn{17}{|l|}{ b) } \\
\hline Verbs & 23 & 30 & 24 & 28 & 23 & 30 & 30 & 23 & 25 & 34 & 31 & 32 & 27 & 32 & 26 & 28 \\
\hline TOPverbs & & 7 & 27 & 35 & 29 & & & 27 & 37 & 17 & & 6 & 28 & 40 & 30 & 23 \\
\hline \multicolumn{17}{|l|}{ c) } \\
\hline Prepos_Connect & 50 & 47 & 32 & 38 & 29 & 43 & 46 & 35 & 35 & 22 & 21 & 22 & 15 & 34 & 23 & 25 \\
\hline \begin{tabular}{|l|} 
Adverbs \\
\end{tabular} & 9 & 11 & 17 & 25 & 23 & 11 & 10 & 16 & 20 & 20 & 10 & 10 & 17 & 24 & 20 & 23 \\
\hline \multicolumn{17}{|l|}{ d) } \\
\hline Direction & 11 & 7 & & & 6 & & 7 & 6 & 6 & & 10 & 7 & 7 & & & \\
\hline Distance_Size & 9 & 10 & & & & 7 & 7 & & & & 9 & 12 & & & & \\
\hline Numbers & 14 & 9 & & & & 11 & 6 & & & & 13 & 10 & & & & \\
\hline \begin{tabular}{|l|} 
Measures \\
\end{tabular} & 12 & 14 & & & & 16 & 10 & & & & 19 & 14 & & & & \\
\hline \multicolumn{17}{|l|}{ e) } \\
\hline Comparisons & & & & & & & & & & & & 8 & & & & \\
\hline Half & 11 & 12 & 14 & 14 & 15 & 13 & 13 & 10 & 13 & 12 & 8 & 6 & & 10 & 13 & 10 \\
\hline Side & & & 7 & & & & & & & & & & & & & \\
\hline \multicolumn{17}{|l|}{ Part } \\
\hline Corner & & & & & & & & & & & & & & & & \\
\hline
\end{tabular}

Blue - significantly less likely use of certain category according to Chi-Square test

Red - significantly more likely use of certain category according to Chi-Square test 
Table 4.2. Frequencies of the words used in the stimuli (Table 1) descriptions according the coded categories (Table 2 and Table 3), \%

\begin{tabular}{|c|c|c|c|c|c|c|c|c|c|c|c|c|c|c|c|}
\hline & \multicolumn{6}{|c|}{ Under (S) } & \multicolumn{4}{|c|}{ Oblique } & \multicolumn{5}{|c|}{ In / Around } \\
\hline & 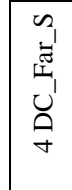 & $\begin{array}{l}n_{1} \\
\vec{J}^{\prime} \\
z_{1} \\
\cup \\
\infty\end{array}$ & $\begin{array}{l}\sim \\
U \\
\simeq \\
\simeq\end{array}$ & $\begin{array}{l}n \\
0 \\
0 \\
0 \\
0\end{array}$ & 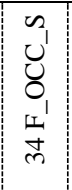 & $\begin{array}{l}n \\
u^{\prime} \\
\bigcup_{0} \\
0 \\
\infty \\
\infty\end{array}$ & 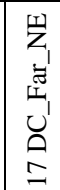 & 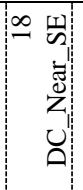 & $\begin{array}{l}3 \\
\infty \\
0 \\
1 \\
0 \\
2\end{array}$ & 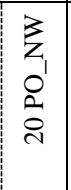 & 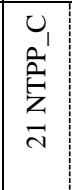 & $\begin{array}{l:}z \\
z\end{array}$ & 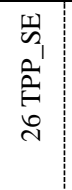 & 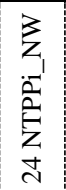 & 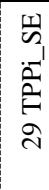 \\
\hline \multicolumn{16}{|l|}{ a) } \\
\hline Dark (Figure) circle & 14 & 14 & 19 & 17 & 16 & 25 & 13 & 12 & 12 & 17 & 14 & 20 & 18 & 31 & 32 \\
\hline \begin{tabular}{|l|} 
Reference \\
(Ground) object
\end{tabular} & 61 & 55 & 63 & 70 & 67 & 66 & 59 & 59 & 58 & 65 & 70 & 73 & 74 & 70 & 63 \\
\hline \begin{tabular}{|l|}
$\begin{array}{l}\text { Both circles } \\
\text { (common parts) }\end{array}$ \\
\end{tabular} & & & 10 & 7 & & & & & 15 & 7 & & & & & 10 \\
\hline \multicolumn{16}{|l|}{ b) } \\
\hline Verbs & 31 & 31 & 29 & 28 & 27 & 28 & 30 & 35 & 30 & 31 & 36 & 40 & 34 & 39 & 33 \\
\hline TOPverbs & & 6 & 20 & 34 & 28 & 20 & & & 27 & 38 & & 6 & 14 & 17 & 19 \\
\hline \multicolumn{16}{|l|}{ c) } \\
\hline Prepos_Connect & 23 & 23 & 11 & 35 & 29 & 23 & 53 & 55 & 45 & 40 & 19 & 24 & 27 & 16 & 18 \\
\hline Adverbs & 12 & 10 & 17 & 16 & 26 & 23 & 10 & 11 & 12 & 18 & & & 6 & 11 & 6 \\
\hline \multicolumn{16}{|l|}{ d) } \\
\hline Direction & 10 & 8 & & & & & 30 & 28 & 28 & 20 & & 9 & 10 & & 7 \\
\hline Distance_Size & 13 & 10 & & 8 & 9 & & 12 & 10 & 6 & & 8 & 7 & & & 8 \\
\hline Numbers & 13 & 6 & & & 8 & & 14 & 12 & 9 & 7 & 6 & 6 & 6 & 7 & 8 \\
\hline Measures & 21 & 15 & & & & & 15 & 14 & 8 & 8 & & 6 & 6 & & \\
\hline \multicolumn{16}{|l|}{ e) } \\
\hline Comparisons & 9 & 7 & 7 & 9 & 6 & & 10 & 7 & 8 & & 13 & 15 & 15 & 17 & 20 \\
\hline Half & & & & 6 & & 6 & 13 & \begin{tabular}{l|l}
9 & \\
\end{tabular} & 11 & 13 & 7 & 19 & 22 & & \\
\hline Side & & & & & & & & & & & & & 7 & & \\
\hline Part & & & & & 8 & & & & & & & & & & \\
\hline Corner & & & & & & & & & & 5 & & & 5 & & \\
\hline
\end{tabular}

Blue - significantly less likely use of certain category according to Chi-Square test Red - significantly more likely use of certain category according to Chi-Square test

The differences between stimuli in each coded category were explored using binary logistic regression modelling employing the following factors: topological relation, proximity, orientation and axial direction (Table 5). Similar results were obtained by applying Chi-square test to separate groups of stimuli distinguished by these factors. For example, all stimuli with $E C$ relation were mutually compared with respect to frequencies in coded categories, thus enabling to assess the impact of different 
orientations, or all stimuli where the dark circle is above the light one were mutually compared with respect to frequencies in coded categories, thus enabling to assess the impact of topological relations.

Table 5. Factors for exploring frequency differences within coded categories

\begin{tabular}{|l|l|l|l|}
\hline 1. Topological relations & $\begin{array}{l}\text { 2. Proximity/ } \\
\text { distance }\end{array}$ & 3. Orientation & $\begin{array}{l}\text { 4. Axial } \\
\text { direction }\end{array}$ \\
\hline DC - disconnectedness & none & to the left (W) & horizontal \\
\hline EC - externally connectedness & near & to the right (E) & vertical \\
\hline PO - partial overlap & far & over (N) & oblique \\
\hline TPP - tangential proper part & under (S) & center \\
\hline $\begin{array}{l}\text { NTPP - non-tangential proper } \\
\text { part }\end{array}$ & & $\begin{array}{l}\text { oblique, left-over } \\
\text { (SW) }\end{array}$ & \\
\hline $\begin{array}{l}\text { TPPi - inverse tangential } \\
\text { proper part }\end{array}$ & $\begin{array}{l}\text { oblique, right-over } \\
\text { (SE) }\end{array}$ & \\
\hline $\begin{array}{l}\text { NTPPi - inverse non-tangential } \\
\text { proper part }\end{array}$ & & $\begin{array}{l}\text { oblique, right-under } \\
\text { (NE) }\end{array}$ & \\
\hdashline $\begin{array}{l}\text { Figure-object occludes } \\
\text { (F_OCC) }\end{array}$ & & $\begin{array}{l}\text { oblique, left-under } \\
\text { (NW) }\end{array}$ & \\
\hdashline $\begin{array}{l}\text { Ground-object occludes } \\
\text { (G_OCC) }\end{array}$ & & center & \\
\hline
\end{tabular}

Further the impacts of the factors included in Table 5 and detected as statistically significant $(\mathrm{p}=0.05)$ by Chi-square tests are described. The tendencies concluded from regression analysis are summarized in Table $7 \mathrm{a}$.

The dark circle (Table $4 \mathrm{a}$ ) is significantly more frequently mentioned for stimuli if it is around the white circle (NPPi, NTPPi) or behind it (Ground-object occludes) while it is less frequently mentioned where both circles are not connected $(D C)$, especially if located to the right.

Similarly, the reference (Ground) object (Table 4a) is referred to differently depending on connectedness. When circles are not connected $(D C)$ the reference object is mentioned less frequently, except for stimuli where the dark circle is in or around the light circle (NTPP, NTPPi). For description of tangential and non-tangential proper part stimuli $(N T P P, T P P)$ the reference object is mentioned most frequently.

Common parts (e.g., shared areas of both circles, common point) (Table 4a) are mentioned less frequently $-5-15 \%$ answers in total for some stimuli. They are more typical for those cases where circles are externally connected $(E C)$ or overlapping $(P O)$.

The use of verbs (Table $4 \mathrm{~b}$ ) does not differ significantly if different stimuli are compared, but the use of TOPverbs (i.e., topological verbs) (Table 4b) differs significantly depending on the topological relation. The main differences in the use of TOPverbs refer to stimuli with overlapping circles $(P O)$ (in these cases, TOPverbs are used most frequently) and stimuli where both circles are not connected $(D C)$ (in this case, TOPverbs are used less frequently). The proximity (distance) does not show any 
significant impact on the use of TOPverbs. Also, the general orientational information horizontal, vertical, oblique and central - shows no significant impact on the use of TOPverbs. When looking in more in detail at the impact of orientation (to the left, to the right, above, under, etc.) - the different frequencies regarding the use of TOPverbs are due to connectedness of the circles.

The prepositions and connectives (Table 4c) are used to a lesser extent for description of stimuli where the dark circle is in the center or around the light circle $(N T P P, N T P P)$ and has partial occlusion with respect to the light circle. Significantly more frequent prepositions and connectives are used for stimuli where circles are not connected $(D C)$ and are located on the horizontal or oblique axis. Regarding the vertical orientation, prepositions and connectives are more frequently used for those stimuli where circles overlap, but less frequently when circles are not connected $(D C)$ or are the cases of objects touching $(E C)$. However, we have to take into account that this category is somewhat subtle and includes different words regarding their function in the description (localization prepositional construction (e.g., to the left ( $p a$ kreisi)), sentence construction (e.g., above and touching (augšpusē un pieskaras)) etc. Thus, the differences may be linked with coding specifics, as we did not develop subcategories according to different contexts. Similarly, the adverb category (Table 4c) includes different words with respect to their context in the description and we are not particularly interpreting the differences. Adverbs most frequently had been used in cases when circles overlap or occludes. In turn, they are less frequently used in more unambiguous situations when the dark circle is inside or around the light circle.

In stimuli where both objects are disconnected, significantly more frequently specifying information is provided as to relational orientation, distance and further measuring (including numerical information) items. The words in stimuli descriptions that correspond to direction category (Table $4 \mathrm{~d}$ ) most frequently are used for the stimuli that refer to the relations where circles are displayed on oblique axis $(20-30 \%)$. However, such tendency is not observed for stimuli with containment (TPP, NTPP, $T P P i, N T P P i)$ where circles are also on the oblique axis. The distance and size information (Table $4 \mathrm{~d}$ ) is mentioned relatively more frequently for those stimuli where circles do not touch $(D C)$ (7-13\%). The same refers to information that characterizes measurements (10-21\%) and includes numerical values (6-14\%) (Table 4d).

Regarding comparison category (Table 4e), most frequently comparison forms are used for containment stimuli (TPP, NTPP, $T P P i, \quad N T P P i)$. For locational generalizations (Table 4e) such as 'side', 'half' and 'edge' most commonly the word 'half' is used and most often it is used for stimuli where the circles are either on the horizontal or oblique axis except for the stimuli where the dark circle is around the light one (TPPi, NTPPi) with the circles on the oblique axis, but overall it is not common to use locational generalizations. In turn, when the dark circle is inside the light one on the oblique axis $(T P P, N T T P)$ use of generalization "half" is significantly more frequent.

In particular, we explored the subcategories that refer to spatial information - the localization prepositions (Table 2) and use of the locative (Table 3). The summary of relative frequencies is provided in Table 6. With the Chi-square test the differences over all stimuli set in each coded category were tested and the significant ones $(\alpha=0.05)$ are marked in blue and red. 
Table 6.1. Frequencies of the words used in the stimuli (Table 1) descriptions according to the coded categories (Table 2 and Table 3), \%

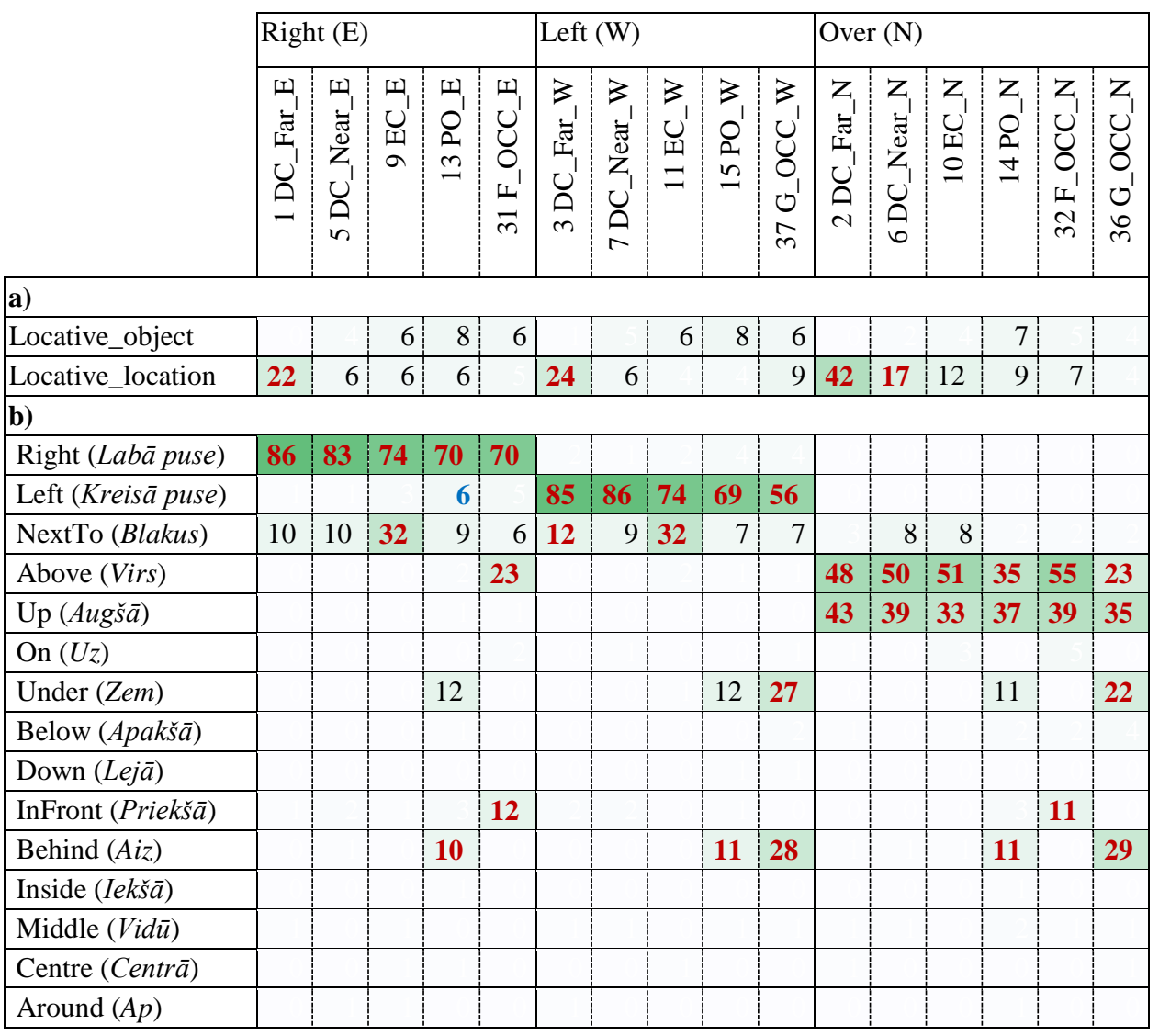

Blue - significantly less likely use of certain category according to Chi-Square test

Red - significantly more likely use of certain category expected according to Chi-Square test

Again, the general tendencies from the Table 6 were tested with Chi Square test within stimuli groups distinguished according to the previously mentioned factors (Table 5). Further the significant $(\mathrm{p}=0.05)$ tendencies have been described.

The locative with respect to a spatial object (Table 6a) is most frequently used for containment stimuli where the dark circle is inside the light one (TPP, NTPP). For containment stimuli with the dark circle around the light one (TPPi, NTPPi) the locative form is also used but to a lesser extent. Also, the oblique axis is a factor supporting the frequency of locative use.

Regarding the use of the location words in the locative (Table 6a) the determining factors are connectedness - more use in such location forms when circles are not connected $(D C)$, and distance - mostly used when circles are far from each other (except 
in the case when the dark circle is under the light one where this distance tendency is opposite).

Table 6.2. Frequencies of the words used in the stimuli (Table 1) descriptions according to the coded categories (Table 2 and Table 3), \%

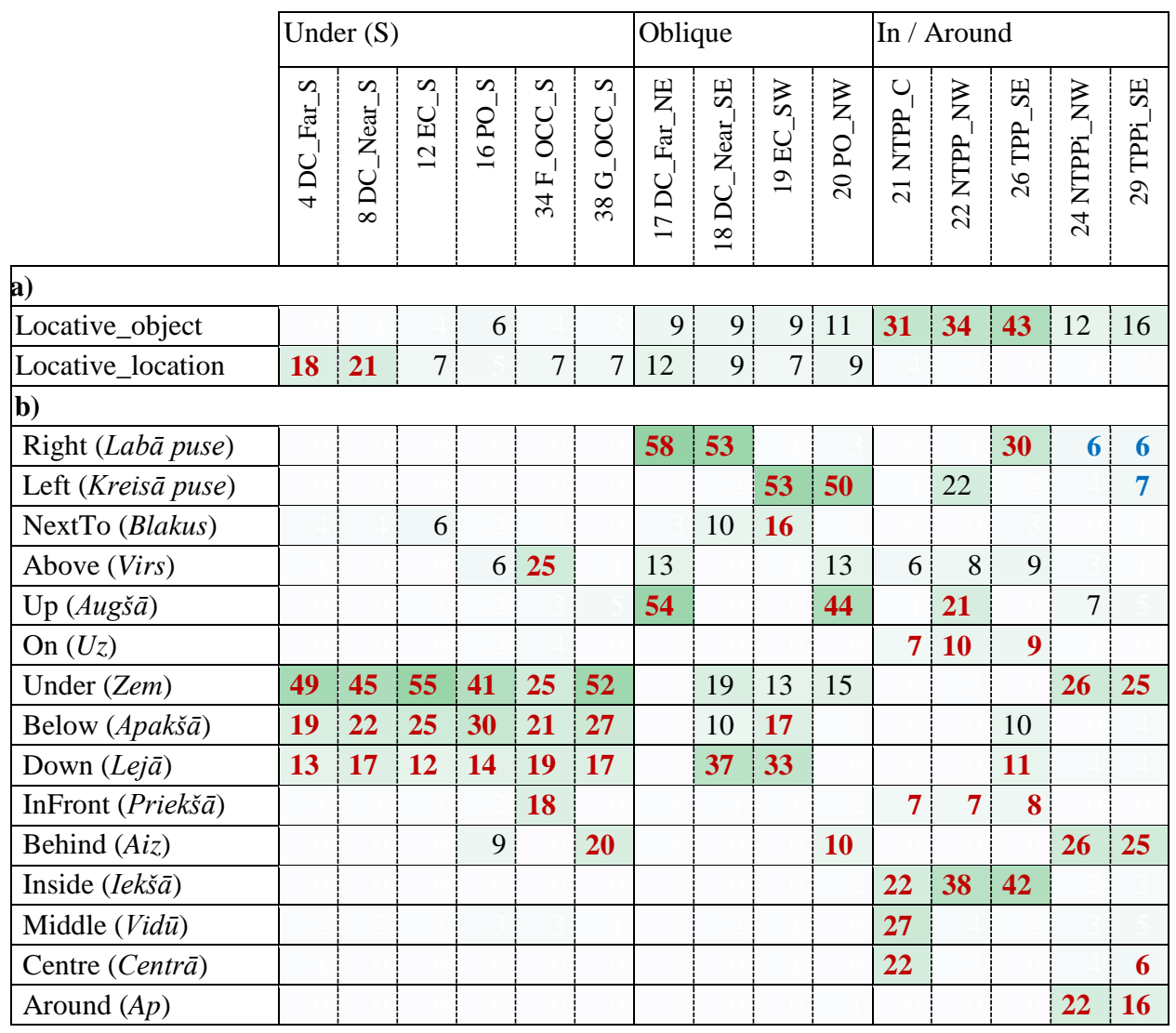

Blue - significantly less likely use of certain category according to Chi-Square test

Red - significantly more likely use of certain category expected according to Chi-Square test

Again, the general tendencies from the Table 6 were tested with Chi Square test within stimuli groups distinguished according to the previously mentioned factors (Table 5). Further the significant $(\mathrm{p}=0.05)$ tendencies have been described.

The locative with respect to a spatial object (Table 6a) is most frequently used for containment stimuli where the dark circle is inside the light one (TPP, NTPP). For containment stimuli with the dark circle around the light one (TPPi, NTPPi) the locative form is also used but to a lesser extent. Also, the oblique axis is a factor supporting the frequency of locative use.

Regarding the use of the location words in the locative (Table 6a) the determining factors are connectedness - more use in such location forms when circles 
are not connected $(D C)$, and distance - mostly used when circles are far from each other (except in the case when the dark circle is under the light one where this distance tendency is opposite).

Obviously, the left and the right orientation (Table 6b) are used for stimuli where the dark circle is on the horizontal axis. Most commonly it is used is for stimuli where the circles are not connected $(D C)$, but the distance does not show significant impact. Similarly, these location words are less but still commonly used for stimuli with the oblique axis (50-58\%). Comparatively less they are used for containment stimuli with the dark circle inside the light one (22-30\%) (TPP, NTTP). For the stimuli with the dark circle around the light one (TPPi, NTPPi) these location words are used rarely and most likely for the description of location of the light circle with respect to the dark one even if the task had been to use it as reference for the light circle.

Interesting is the use of the location 'next to'(Table 6b). Most commonly it is used for topological relation where circles are externally connected $(E C)$ (most pronounced effect on the horizontal axis), but there is tendency to use it also for the relation when circles are not connected $(D C)$ but lie on the horizontal axis.

The most common location words used for the 'over' (North direction) (Table 6b) are Up and Above. These words are commonly used also for the stimuli where the dark circle is in front of the light circle (stimuli 31, 32, and 34, Table 1) indicating the $3 \mathrm{D}$ perspective. Also, the containment stimuli descriptions indicate that 3D perspective has been used, e.g., for stimuli 21 and 26 (Table 1). For the oblique axis, a more typical way of interpreting the 'above' it is to use the word Up.

The most common location words used for the 'under' (South direction) (Table 6b) are Under, Below and Down. The location word Under seems to be characteristic for $3 \mathrm{D}$ perspective, as it is used for the stimuli where circles overlap or the dark circle is behind the light one, as well as in the case when the dark circle is around the light one $(T P P i, N T P P i)$. The Under and Below locations are used also for the oblique axis stimuli, however Down is more frequently used for these situations. Below and Down are also among the descriptions of stimuli where the dark circle is inside the light one externally connected at a point in oblique direction (stimuli 24 , Table1).

In front location is used for descriptions of stimuli where the dark circle is in front of the light circle (Figure-object occludes, stimuli 31, 32, and 34) (Table 6b). We can also observe 3D perspective for those stimuli where the dark circle is inside the light circle (TPP, NTPP, stimuli $21,22,26)$, but the frequencies are relatively small $(7-8 \%)$. More pronounced this perspective is in case when the dark circle is around the light one (TPPi, NTPPi, stimuli 24, 29), and Behind is used for description in around $25 \%$ cases. Use of Behind reflects also in the stimuli where circles overlap ( $P O$, Stimuli 13-16) around $10 \%$ cases. For the stimuli where the dark circle is behind the light one (Groundobject occludes, stimuli 36, 37, 38) the use of Behind varies from 20-29\%.

For the description of proper part stimuli where the dark circle is inside the light one (TPP, NTPP) the commonly used location is Inside and in case of central location of the dark circle (stimuli 21) - also Middle and Center. In the situation when the dark circle is around the light one (TPPi, NTPPi) the commonly used location is Around, but just $16-22 \%$, demonstrating that $2 \mathrm{D}$ perspective is less common if compared to the situation when the dark circle is Figure rather than Background. 
Further differences between the stimuli in each coded category were explored by binary logistic regression modelling using factors that are defined in Table 5. The results are summarized in Table $7 \mathrm{~b}$.

Table 7. Significant factors according regression analysis for coded categories

a)

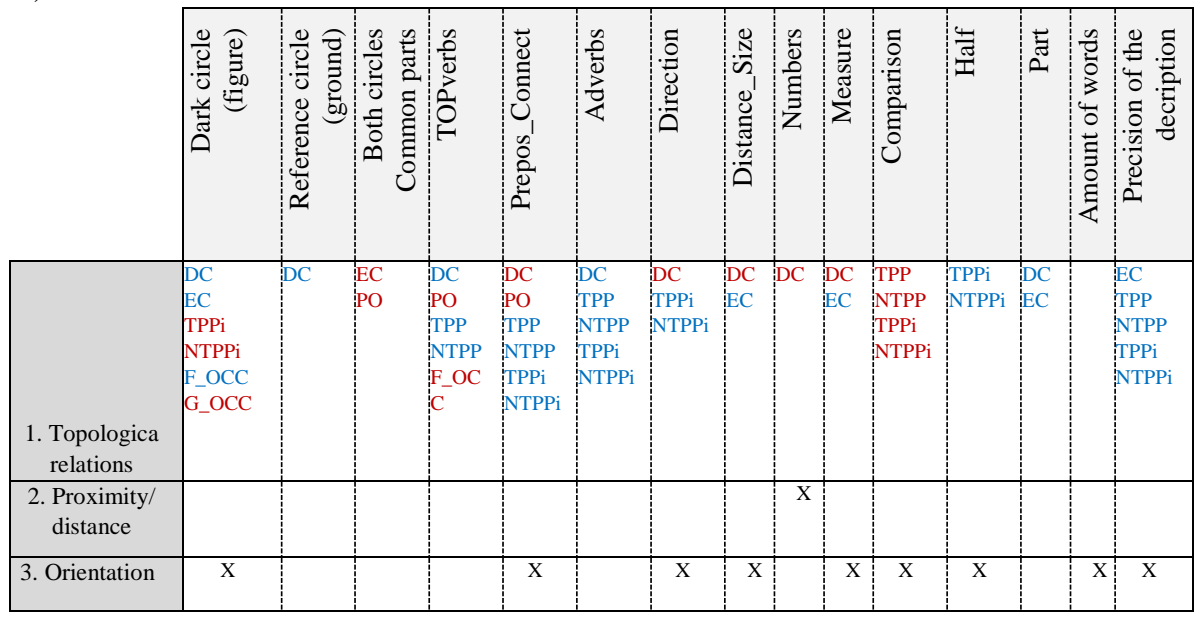

Blue - factor pointing to less likely use of certain category

Red - factor pointing to likely use of certain category

$\mathrm{X}$ - significant factor group

b)

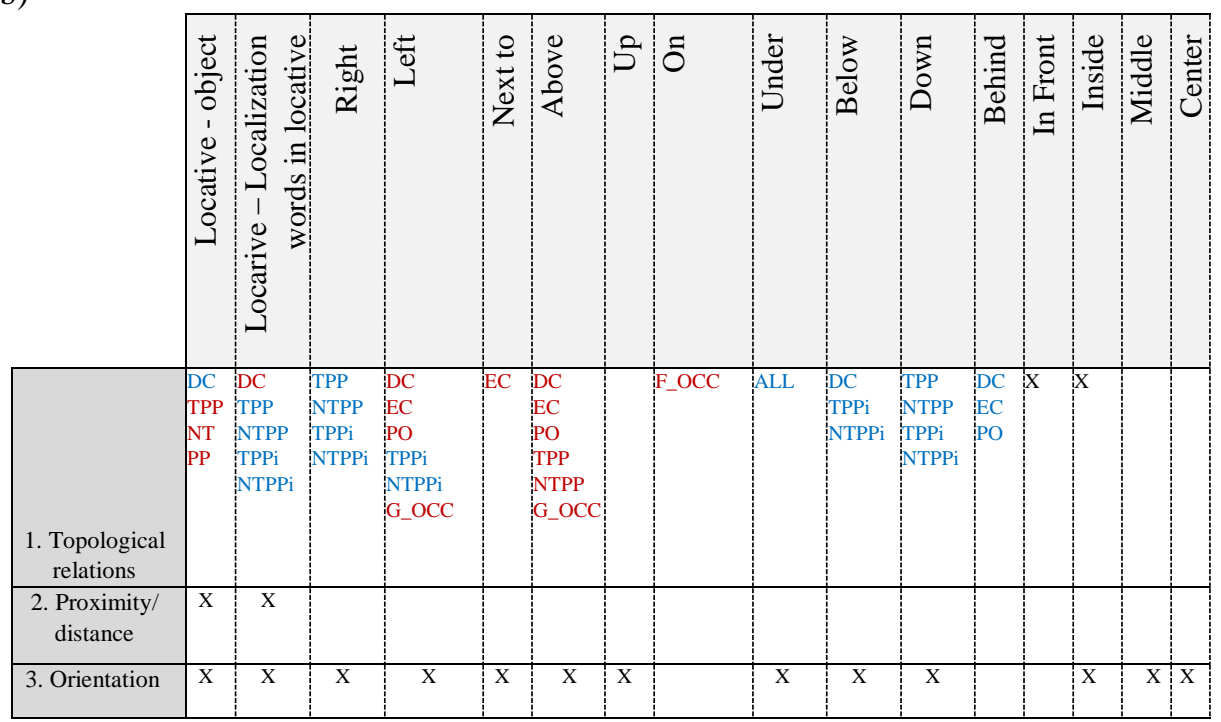

Blue - factor pointing to less likely use of certain category

Red - factor pointing to likely use of certain category

$\mathrm{X}$ - significant factor group 
Different stimuli were described by different number of words and also the accuracy of the localization (Table 3) was given at different level. The length of descriptions seems to correlate with the degree of specificity that is needed to communicate the relation unambiguously. According to our results, we can observe that the more words are used the more accurately the location of the dark circle is given (Spearman's rho $=0.786$, significance level $=0.01$ ). Therefore, the systematic differences between relations in terms of the length of their descriptions indicate that not all relations are equally specific and require more descriptive details.

There was no significant difference (t-test (words), Mann-Whitney $U$ test (localization) for each stimuli, $\alpha=0.05$ ) between these indicators depending on whether the answers were obtained in a paper pencil test or in online survey (except, for the stimulus '5 Close_Right' the localization description precision was statistically different (Mean_e-task=1.77, Mean_ptask=1.36). Accordingly, further analysis was conducted taking into account these differences, but when possible - the electronic and paper answers were analyzed together as equal.

By paired sample t-test (words) and Wilcoxon Signed-Rank test (localization) we tested the differences depending on stimuli and were able to formulate several homogenous subgroups regarding the number of words and localization precision (Figure 1, Figure 2).

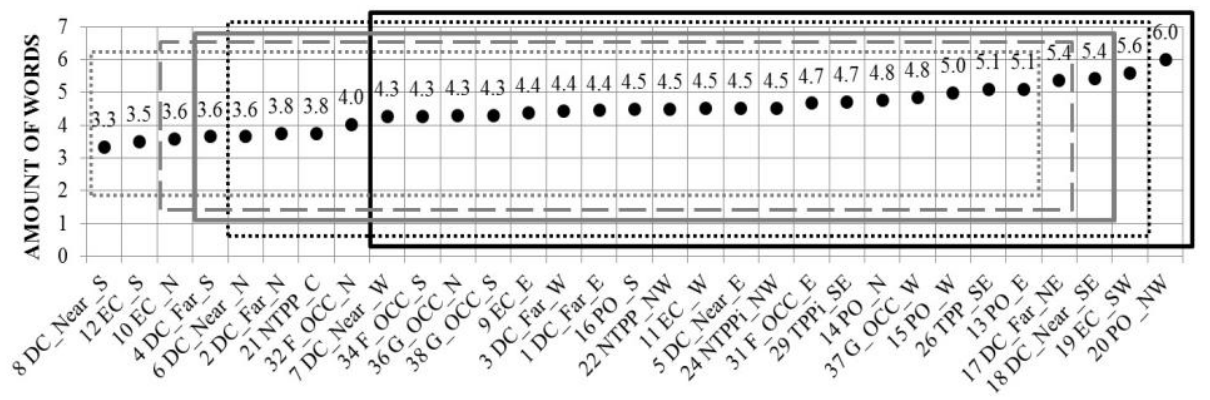

Figure 1. Average number of words used for each subset of stimuli description with significantly different subgroups of stimuli.

Data show that fewest words are used for the stimuli that describe vertical direction in simple topological relations (not connected $(D C$, far and close) and connected at one point $(E C)$ ) as well as inside the central area (Stimuli 21). Most words are used for the same simple relations $(D C, E C)$ when the direction is oblique. Most words in average are used for the situation of overlapping in oblique direction which might indicate that this relation is descriptively most complex. Also, other overlapping situations are described with more words than the same directions for other topological relations (not connected $(D C)$, connected $(E C)$, partial occlusion with respect to the light circle (behind $\left(G_{-} O C C\right)$, in front $\left.\left(F \_O C C\right)\right)$ ). We conducted linear regression analysis using the factors listed in Table 5. The obtained model pointed to orientation as a significant factor (Table 7a). 


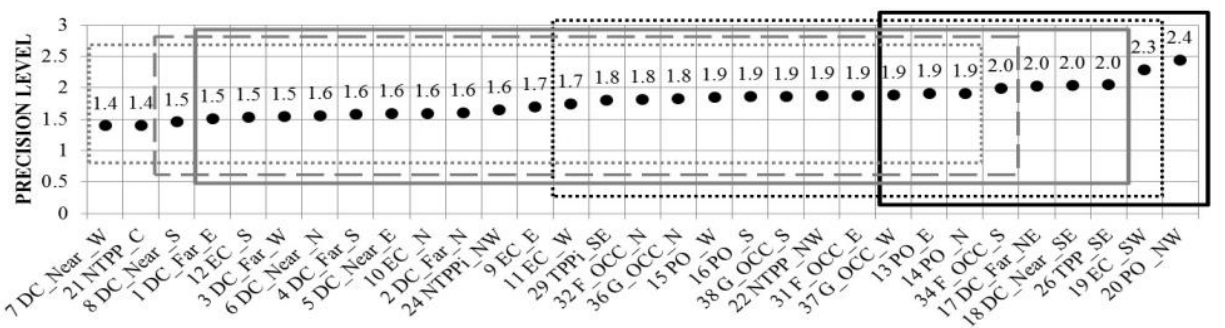

Figure 2. Average level of accuracy (Table 3) for each subset of stimuli description with significantly different subgroups of stimuli.

A more detailed localization is given for the relations that have oblique direction. Regarding topological relations, a more detailed localization is characteristic for situations when circles overlap or are connected one in front/behind the other. The differences in accuracy of the description were explored using ordinal regression analysis. The obtained model pointed to significance of both topological relation and orientation factors (Table 7a).

Generally, our results indicate the most common spatial words in Latvian describing general topological relations and certain geometrical properties such as direction, proximity and object size. In total, relatively diverse array of words were used for describing different localization subgroups (summarized in ANNEX I and ANNEX II).

Analysis of the descriptions points to tendencies characteristic to different topological relations and geometrical features. We were able to detect that different independent variables (Table 5) have different impact on different word categories introduced in the study before and during coding (Table 4, 6, and 7). There are topological relations that are described relatively more frequently by TOPverbs while measurement words are used for object size and distance specification. Also, several locational generalizations such as 'side', 'half' and 'edge' are used to describe some region of the object.

If orientation is tested, in horizontal cases the most frequent and unambiguous are cardinal reference frame-based relations 'to the left of' and 'to the right of', however, once the relations are EC, additional adjacency operator - 'blakus' (next to) is applied (cp. Table 6). In vertical alignment, the interpretation is less homogenous - to a different extent 'virs' (above) and 'augšâ' (up) are most frequent descriptions modulated by three-dimensional interpretation. If the profiles of 'augšă' (up) and 'virs' (above) are compared, 'augšā' (up) seems to have a more balanced and for a larger variety applicable set of uses.

If inverse relations are considered (where the figure is in the lower part) then 'zem' (under) seems to have the widest and most frequent profile of interpretation used in all stimuli. In general, we can observe that lower part descriptions of vertical alignment are less homogenous and relations represented by upper and lower part are less symmetric than those represented by horizontal alignment (i.e., left and right ones). However, horizontal descriptions contain significantly more words which is because descriptions 'to the right of' and 'to the left of' (or 'on the left side of' or 'on the right 
side of_') consist of several words each. Partly this might also indicate that relations based on the vertical alignment are less ambiguous (Figure 1).

Generally, topological relations are significant factors for every category. A significant feature of the perception of $P O$ is three-dimensionality. Stimuli 31 and 37 (and inversely - 15 and 37) are perceived three-dimensionally but the three-dimensional interpretation is more dominating in the case where the figure object partially overlaps without transparency effects than in case if the overlapping figure is transparent. I.e., the transparent cases (13 and 15) are interpreted less three-dimensionally than not transparent ones (31 and 37). This might eventually be because of the perceptual effects of amodal completion. These descriptions contain 'virs' (above) 25\%, 'priekšā' (in front of) $12 \%$ and 'zem' (under) 27\% , 'aiz' (behind) 28\% (see Table 6). Somewhat similar pattern of results arises in vertical interpretation. Cases of non-transparent overlapping (stimuli 32, 34, 36, and 38) allow three-dimensional interpretation of 'aiz' (behind) and 'priekšā' (in front of) again eventually in virtue of amodal completion.

In total, there is a variety of answers in our results sharing the principle that the figure and ground object are bound by a spatial relation $R(F, G)$.

In most cases, they can be put in an ordered sequence $\langle F, R, G\rangle: R \in \mathrm{RCC}+\mathrm{F}$, where the complete version would be either

$[\text { The black square }]_{\text {Figure }}[\text { is }]_{\text {Verb }}[\text { in front of }]_{P P}[\text { the white circle }]_{\text {Ground }}$

or

$[\text { The black square }]_{\text {Figure }}[\text { is put }]_{\text {Verb }}[\text { on the top of }]_{P P}[\text { the white circle }]_{\text {Ground }}$.

According to Landau et al. (Johannes et al., 2016a, b, Landau et al., 2017), the latter case contains a lexical verb which contributes to the meaning of expression, whereas the former case contains a copular verb which in turn does not significantly contribute to the overall meaning of the expression. According to Landau's framework, lexical verbs are more force-dynamic than geometric. Further, gravitational support as the core relation of support (also when compared cross-linguistically and developmentally, cp. Landau et al. (2017). According to our results that we explore in a more detail elsewhere (Žilinskaite-Šinkūniene et al., 2019), in functionally simple stimuli also (such as RCC+F) we can observe different and complex impacts of support and containment on the interpretation of spatial relations and their representation in natural language.

\section{Discussion}

A general observation is that the horizontally aligned configuration induces a more symmetric, whereas vertical - less symmetric interpretation. Eventually this is because of support relation operating in vertical alignment. According to previous research ((Maki et al., 1977), for discussion: (Newcombe and Huttenlocher, 2000, 185f.)), horizontal and vertical axial structures seem to be difficult and salient to a different degree; horizontal axial information (left / right) is more difficult than vertical (above / below) and vertical axis seems to be more salient which is also reflected why 'south/ north' is recognized easier than 'east/ west' (Loftus, 1978). As to the difference in the strength of axial structures, (a) the vertical axis is gravity determined and therefore the 
strongest, whereas (b) front-back is weaker, and the most difficult is (c) the left-right axial structure (Newcombe and Huttenlocher, 2000).

Notwithstanding the differences mentioned before, our results seem to support the view that vertical and horizontal alignments are cognitively more prominent with respect to other relations (cp. (Hayward and Tarr, 1995)).

According to several recent studies by Barbara Landau and her colleagues (cp. (Johannes et al., 2016b) which used natural scenes, basic locative expressions and expressions of support seem to represent a part of the core of spatial knowledge that is relatively robust in developmental terms. Further, gravitational support is most prominent if natural scenes are observed; in our simplified stimuli we cannot see the detailed structure support or containment (as in the case of everyday objects), some functional constraints might eventually apply, e.g., if vertical and horizontal alignments are compared (for a more detailed discussion of support and containment in Baltic languages cp. (Žilinskaite-Šinkūniene et al., 2019)).

Proximity as a factor seems to be important but to a different degree in different cases. It seems to impact the use of 'blakus' (next to).

According to our results, relational descriptions are preferred over metric or continuous ones (which tends to support findings by Lovett and Franconeri (2017), cp. also Yuan et al. (2016)). Relational descriptions that enable segmenting space into rather discrete categories are preferred with a relative consistency. Further, relatively precise topological expressions (using TOPverbs) are applied. We might also agree that categorical relations between objects seem to be more stable than changes in size (Lovett and Franconeri, 2017).

However, the fact that observers segment spatial relations categorically does not mean that the categories are mutually exclusive; rather categories overlap and fuzzy category borders seem to be the case in most situations (Newcombe and Huttenlocher, 2000,183 ). There are spatial descriptors that are more universal (or prototypic) for certain relations (e.g., 'virs' (above)) and some that are more specific ('uz'(on)). Eventually, we might hypothesize that the most prototypical descriptions are used to understand the less prototypic ones (Newcombe and Huttenlocher, 2000, 184).

According to our results, topological relations (e.g., $E C$ vs. $D C$ ) seem to be relatively primary with respect to geometric ones; however, this is a tentative statement since the object form, distance and angular information seem to have a more complex determining role too and will be explored in an upcoming paper. The primacy of topological descriptions also supports findings by Knauff et al. (1997). According to their results, most of the descriptions of RCC relations are topological and there is only a small number of combinations of topological and orientational $(14,1 \%)$ and topological and metric information (19,2\%) (Knauff et al., 1997).

We also agree that topological relations are primary with respect to fine-grained geometric relations and that processing of spatial information is most likely a stage-wise process where objects (their topological boundaries) are discriminated in the first stage, then primary relations are generated and more detailed geometric knowledge is added at a later point (cp. also (Franconeri et al., 2012), (Xu and Franconeri, 2012), (Choo et al., 2012), (Chen, 2005a, b)).

Consistent with the idea that primary processing stage is topologic, we agree with Palmer and Rock (1994) about the principle of uniform connectedness stating that the primary operation is generation of perceptual units that takes place in virtue of 
connectedness and is occurring at an entry level of perception and is therefore prior to grouping. Although we assume that basic topological relations (complemented with some geometric and functional primitives) allow optimal representation of spatial relations, we were able to show that not all topological and geometric relations are interpreted equally: e.g., some have a wider scope of interpretation and some narrower; some seem to induce a more precise description, whereas others - less (E.g. 'under' and 'on' can be interpreted in 2D and 3D perspectives, but 'centre' can be interpreted unambiguously).

Our results indirectly support Roth and Franconeri (2012) findings about asymmetric coding of spatial relations. E.g., 'black circle is below the white circle' is interpreted differently than 'white circle is below the black circle'. This is reflected in the principle that an object that has to be located needs another object providing a reference area where the former is located. Roth and Franconeri (2012) showed the effect of this asymmetry by using the analysis of selective attention and arguing that attention is mapped onto one object at a time; the figure object is marked by the spotlight of attention. According to these results, asymmetry in spatial coding seems to be shared by perceptual and linguistic levels. In our case this distinction can be nicely seen in linguistic descriptions induced by

$$
Q \text { : Where is } F \text { ? }
$$

and observing the answer

$$
A: R(F, G)
$$

which in virtue of the asymmetry can be expressed in an ordered triplet $\langle F, R, G\rangle$, e.g., $\langle$ Circle, in front of, square〉, indicating that canonical interpretation binds figure and ground object with a relation - prepositional or otherwise (for an application and discussion of figure and ground relationship as a spatial extraction principle within georeferencing approach cp. (Chen et al., 2017.)).

In perceptual terms, our results eventually also support the findings by Lester et al. (2009) that figural regions are available for perceptual processing before the grounds; however, this seems to be the case only when figure and ground are not spatially separated or at least share an edge.

We also argue that proximity impacts the perception of topological and geometric relations but to a more complex degree in case of each relation. Although spatial proximity seems to be a more crucial factor than others (Franconeri et al, 2012), its impact is different in different configurations.

Our results seem to at least partially to support the view proposed by Chen (2005a, b, 1982) that primary level of perceptual processing is topological both in terms of object individuation and spatial relations: according to Chen topological relations and topological organization based on physical connectedness are primary with respect to geometric (based on distance). In our case, topological relations are more detailed than geometric ones. However, distance plays a crucial role in some of the relations, according to our results. Another explanation might be that a certain tolerance space (Peters and Wasilewski, 2012) generation principle applies according to which some elements (close to one another) are perceived as one or belonging to one another.

Connectedness as a core topological feature (Chen, 1982) seems to have impact in the interpretation of spatial relations which is also consistent with our results (cp. Table 7 reflects the significance for several categories). 
Once we have geometrical primitive of nearness, the formal level of our approach is compatible with tolerance and nearness models ((Peters, 2007), (Peters and Wasilewski, 2009, 2012); for an analysis of proximity cp. also (Peters and Guadagni, 2016)).

In fact, the idea of tolerance qualities is close to the principle of proximity by Claude Vandeloise: "A point acquires the quality of another point as long as it is not closer to a third point bearing the contradictory quality." (1991, 48) Although the principle of proximity according to Vandeloise applies to functional relations and contexts, it makes perfect sense to be used for topological settings as well.

Finally, our work supports the results and generalizations by Klippel et al. (2013). According to our findings not all topological relations are equally prominent and some geometric factors (such as orientation and distance) matter as well. Although we did not test different semantic domains (as done in the studies by Klippel) we made a more careful analysis of RCC-based spatial relations that are relatively neutral in terms of semantic domain and therefore our results can serve as a precise foundational basis for exploring other domains. To sum up, according to our results, we would like to argue that topology is not sufficient to generate a cognitively valid model of spatial representation - some geometrical and functional primitives are also needed. Although we have not tested other than static stimuli, we agree that dynamic stimuli and stimuli reflecting the manner of motion shape the perception of the 'underlying' topology. Finally, we assume that topology and geometry, and functional factors have different temporal properties - it might be the case that topology matters at the temporarily primary level but is context-dependently modulated by geometric and functional constraints at a slightly later point.

Our work shows cognitive relevance and plausibility of an RCC-based model. Although spatial representations are always to some extent language-dependent, natural languages never exactly encode metric relations (instead relational representations are used) (cp. (Newcombe and Huttenlocher, 2000)) enabling RCC to be a cognitively plausible and sensitive way of expressing relational representations of spatial language.

\section{Conclusions}

According to our results, (1) proximity seems to be a sensitive independent variable - when using a larger distance between $F$ and $G$ in several spatial relations a larger percentage of consistent descriptions are generated by users whereas if the distance is smaller the variety of other descriptions is increasing. However, proximity and distance impact only some relations (cp. Table 7). (2) In all spatial relations (but to a different degree in each) a set of topological verbs is used that relatively precisely describe the spatial relations (Table 4). (3) in most $\mathrm{RCC}+\mathrm{F}$ relations spatial relations are encoded and linguistically represented categorically instead of encoding fine-grained details. (4) It seems that the most robust topological relations can be grouped into (a) those where there are no shared points between both objects (basically all varieties of $D C$ ) and (b) contained objects (TPP and NTPP). (5) Topological and geometric (e.g., axial alignment, distance) relations matter but to a different degree. (6) In case of different relations, different descriptive accuracy can be achieved. Finally, (7) we have 
tested both paper-and-pencil and digital versions and were not able to see significant differences in the description accuracy of $\mathrm{RCC}+\mathrm{F}$ relations between both formats. However, we have left for further studies the analysis of the use of different location prepositions for the same configuration or differences between word use depending on the test version ( $\mathrm{p}$-task vs e-task). Therefore, we might assume that there are subtler differences between both formats.

Our study extends the understanding of how topological relations are encoded in natural language (e.g., topological verbs show a relatively precise set of descriptive tools worth to be explored in future studies). Our results can also be used in natural language systems when more precise descriptive tools are necessary for representing spatial relations.

\section{Acknowledgements}

This research has been supported by the European Regional Development Fund within the project "Neural Network Modelling for Inflected Natural Languages" No.

1.1.1.1/16/A/215.

\section{References}

Amir, O., Biederman, I., Herald, S. B., Shah, M. P., Mintz, T. H. (2014). Greater sensitivity to nonaccidental than metric shape properties in preschool children. Vision Research, 97, 83-88.

Aurnague, M., Vieu, L. (1993). Toward a formal representation of space in language: A commonsense reasoning approach. In IJCAI-93 workshop on spatial and temporal reasoning (pp. 123-158).

Carlson, L. A., Hill, P. L. (2007). Experimental methods for studying language and space. In M. Gonzalez-Marquez, I. Mittelberg, S. Coulson, M.J. Spivey (Eds.), Methods in Cognitive Linguistics (pp. 250-276). Amsterdam: John Benjamins Publishing.

Chen, H., Vasardani, M., Winter, S. (2017). Geo-referencing Place from Everyday Natural Language Descriptions. arXiv preprint arXiv:1710.03346. Chen, L. (1982). Topological structure in visual perception. Science, 218(4573), 699-700.

Chen, L. (2005a). The topological approach to perceptual organization. Visual Cognition, 12(4), 553-637.

Chen, L. (2005b). Author's response: Where to begin? Visual Cognition, 12(4), 691-701.

Choo, H., Franconeri, S. L. (2010). Visual size averaging of objects unavailable to conscious awareness. Attention, Perception, \& Psychophysics, 72(1), 86-99.

Choo, H., Levinthal, B. R., Franconeri, S. L. (2012). Average orientation is more accessible through object boundaries than surface features. Journal of Experimental Psychology: Human Perception and Performance, 38(3), 585-588.

Clementini, E., Di Felice, P., Van Oosterom, P. (1993). A small set of formal topological relationships suitable for end-user interaction. In D. Abel, B.C. Ooi (Eds.), Advances in spatial databases. Third International Symposium on Spatial Databases (pp. 277-295). Berlin: Springer.

Cohn, A. G., Bennett, B., Gooday, J., Gotts, N. M. (1997). Qualitative spatial representation and reasoning with the region connection calculus. GeoInformatica, 1(3), 275-316. 
Coventry, K. R., Garrod, S. C. (2004). Saying, seeing and acting: The psychological semantics of spatial prepositions. Hove: Psychology Press.

Coventry, K. R., Prat-Sala, M., Richards, L. (2001). The interplay between geometry and function in the comprehension of over, under, above, and below. Journal of memory and language, 44(3), 376-398.

Davis, E., Marcus, G., Frazier-Logue, N. (2017). Commonsense reasoning about containers using radically incomplete information. Artificial Intelligence, 248, 46-84.

Della Penna, G., Magazzeni, D., Orefice, S. (2017). A formal framework to represent spatial knowledge. Knowledge and Information Systems, 51(1), 311-338.

Düntsch, I., Wang, H., McCloskey, S. (2001). A relation-algebraic approach to the region connection calculus. Theoretical Computer Science, 255(1), 63-83.

Egenhofer, M. J., Franzosa, R. D. (1991). Point-set topological spatial relations. International Journal of Geographical Information System, 5(2), 161-174.

Forbus, K. D., Chang, M., McLure, M., Usher, M. (2017). The cognitive science of sketch worksheets. Topics in cognitive science, 9(4), 921-942.

Forbus, K.D. (2018). Qualitative representations: how people reason and learn about the continuous world. Cambridge, MA: The MIT Press.

Franconeri, S. L., Pylyshyn, Z. W., Scholl, B. J. (2012). A simple proximity heuristic allows tracking of multiple objects through occlusion. Attention, Perception, \& Psychophysics, 74(4), 691-702.

Franconeri, S. L., Scimeca, J. M., Roth, J. C., Helseth, S. A., Kahn, L. E. (2012). Flexible visual processing of spatial relationships. Cognition, 122(2), 210-227.

Gentner, D., Imai, M., Boroditsky, L. (2002). As time goes by: Evidence for two systems in processing space $\rightarrow$ time metaphors. Language and cognitive processes, 17(5), 537-565.

Gerevini, A., Renz, J. (2002). Combining topological and size information for spatial reasoning. Artificial Intelligence, 137(1-2), 1-42.

Haun, D. B., Rapold, C. J., Janzen, G., Levinson, S. C. (2011). Plasticity of human spatial cognition: Spatial language and cognition covary across cultures. Cognition, 119(1), 7080.

Hayes, P.J. (1985). The second naïve physics manifesto. In J. Hobbs, B. Moore (Eds.), Formal theories of the commonsense world (pp. 1-36). Norwood, NJ: Ablex Publishing Corporation.

Hayward, W. G., Tarr, M. J. (1995). Spatial language and spatial representation. Cognition, 55(1), 39-84.

Holmes, K. J., Moty, K., Regier, T. (2017). Revisiting the role of language in spatial cognition: Categorical perception of spatial relations in English and Korean speakers. Psychonomic bulletin \& review, 24(6), 2031-2036.

Jamrozik, A., Gentner, D. (2015). Well-hidden regularities: Abstract uses of in and on retain an aspect of their spatial meaning. Cognitive Science, 39.1881-1911.

Johannes, K., Wilson, C., Landau, B. (2016a). Systematic feature variation underlies adults' and children's use of in and on. In Proceedings of the 38th Annual Meeting of the Cognitive Science Society (pp. 2429-2434).

Johannes, K., Wilson, C., Landau, B. (2016b). The importance of lexical verbs in the acquisition of spatial prepositions: The case of in and on. Cognition, 157, 174-189.

Klippel, A., Li, R., Yang, J., Hardisty, F., Xu, S. (2013). The Egenhofer-Cohn Hypothesis or, Topological Relativity? In M. Raubal et al. (Eds.), Cognitive and linguistic aspects of geographic space (pp. 195-215). Springer, Berlin, Heidelberg.

Kluth T, Burigo M, Schultheis H, Knoeferle P (2017) In: Proceedings of the 10th Embodied and Situated Language Processing Conference, Moscow, Russia. Moscow, Russia: 26-27. 
Knauff M., Rauh R., Renz J. (1997) A cognitive assessment of topological spatial relations: Results from an empirical investigation. In S.C. Hirtle, A.U. Frank (Eds.). Spatial Information Theory: A Theoretical Basis for GIS. COSIT 1997. Lecture Notes in Computer Science, vol 1329. (pp. 193-206). Springer: Berlin, Heidelberg. https://doi.org/10.1007/3-540-63623-4_51

Knauff, M. (1999). The cognitive adequacy of Allen's interval calculus for qualitative spatial representation and reasoning. Spatial Cognition and Computation, 1(3), 261-290.

Kosslyn, S. M., Murphy, G. L., Bemesderfer, M. E., Feinstein, K. J. (1977). Category and continuum in mental comparisons. Journal of Experimental Psychology: General, 106, $341-375$.

Kracht, M. (2002). On the semantics of locatives. Linguistics and Philosophy, 25(2), 157-232. Maki, R. H., Maki, W. S., Marsh, L. G. (1977). Processing locational and orientational information. Memory \& Cognition, 5(5), 602-612.

Kranjec, A., Cardillo, E. R., Schmidt, G. L., Chatterjee, A. (2010). Prescribed spatial prepositions influence how we think about time. Cognition, 114(1), 111-116.

Landau, B. (2017). Update on "what" and "where" in spatial language: a new division of labor for spatial terms. Cognitive science, 41(S2), 321-350.

Landau, B. (2017). Update on "what" and "where" in spatial language: a new division of labor for spatial terms. Cognitive science, 41(S2), 321-350.

Lester, B. D., Hecht, L. N., Vecera, S. P. (2009). Visual prior entry for foreground figures. Psychonomic Bulletin \& Review, 16(4), 654-659.

Loftus, G. R. (1978). Comprehending compass directions. Memory \& Cognition, 6(4), 416-422.

Logan, G.D., Sadler, D.D. (1996). A computational analysis of the apprehension of spatial relations. In P. Bloom, M.A. Peterson, L. Nadel, M.F. Garrett (Eds.). Language and space (pp. 493-529). Cambridge, MA: MIT Press.

Lovett, A., Franconeri, S. L. (2017). Topological relations between objects are categorically coded. Psychological science, 28(10), 1408-1418.

Mantle, M., Batsakis, S., Antoniou, G. (2019). Large scale distributed spatio-temporal reasoning using real-world knowledge graphs. Knowledge-Based Systems, 163, 214-226.

Mani, I., Pustejovsky, J. (2012). Interpreting motion: Grounded representations for spatial language. Oxford: Oxford University Press.

Munnich, E., Landau, B. (2010). Developmental decline in the acquisition of spatial language. Language Learning and Development, 6(1), 32-59.

Newcombe, N. S., Huttenlocher, J. (2000). Making space: The development of spatial representation and reasoning. Cambridge, MA: The MIT Press.

Palmer, S., Rock, I. (1994). Rethinking perceptual organization: The role of uniform connectedness. Psychonomic bulletin \& review, 1(1), 29-55.

Peters, J. F. (2007). Near sets. General theory about nearness of objects. Applied Mathematical Sciences, 1(53), 2609-2029.

Peters, J. F., Guadagni, C. (2016). Strongly proximal continuity \& strong connectedness. Topology and its Applications, 204, 41-50.

Peters, J. F., Wasilewski, P. (2009). Foundations of near sets. Information Sciences, 179(18), 3091-3109.

Peters, J. F., Wasilewski, P. (2012). Tolerance spaces: Origins, theoretical aspects and applications. Information Sciences, 195, 211-225.

Plumert, J. M., Carswell, C., Devet, K., Ihrig, D. (1995). The content and organization of communication about object locations. Journal of Memory and Language, 34(4), 477498.

Pustejovsky, J., Lee, K. (2017). Enriching the Notion of Path in ISO-Space. In Proceedings of the 13th Joint ISO-ACL Workshop on Interoperable Semantic Annotation (ISA-13).

Randell, D. A., Cui, Z., Cohn, A. G. (1992). A spatial logic based on regions and connection. KR, 92, 165-176. 
Rodrigues, E., Santos, P. E., Lopes, M. (2017). Pinning down polysemy: A formalisation for a Brazilian Portuguese preposition. Cognitive Systems Research, 41, 84-92.

Roth, J., Franconeri, S. (2012). Asymmetric coding of categorical spatial relations in both language and vision. Frontiers in psychology, 3, 464.

Skilters, J., Zarina, L., Glanzberg, M., Zilinskaite, E. (in prep.) RCC+F: some applications in Baltic languages.

Shen, J., Chen, M., Yue, S. (2018). A distance-based topological relation model between spatial regions. Arabian Journal of Geosciences, 11(23), 763.

Stell, J. G. (2000). Boolean connection algebras: a new approach to the Region-Connection Calculus. Artificial Intelligence, 122(1-2), 111-136.

Svenonius, P. (2006) The emergence of axial parts. Nordlyd: Tromsø Working Papers in Linguistics, 33.1, 49-77.

Talmy, L. (1975). Figure and ground in complex sentences. In Annual Meeting of the Berkeley Linguistics Society, Vol. 1, pp. 419-430.

Taylor, H. A., Tversky, B. (1996). Perspective in spatial descriptions. Journal of memory and language, 35(3), 371-391.

Vandeloise, C. (1991). Spatial prepositions: A case study from French. Chicago: The University of Chicago Press.

Vasardani, M., Stirling, L. F., Winter, S. (2017). The preposition at from a spatial language, cognition, and information systems perspective. Semantics and Pragmatics, 10.

Vieu, L. (1997). Spatial representation and reasoning in artificial intelligence. In O. Stock (Ed.). Spatial and temporal reasoning (pp. 5-41). Dordrecht: Springer.

Xu, Y., Franconeri, S. L. (2012). The head of the table: Marking the "front" of an object is tightly linked with selection. Journal of neuroscience, 32(4), 1408-1412.

Yuan, L., Uttal, D., Franconeri, S. (2016). Are categorical spatial relations encoded by shifting visual attention between objects? PloS one, 11(10), e0163141.

Zilinskaite-Sinkuniene, E., Šķilters, J., Zariņa, L. (2019). Containment and support in Baltic languages: Overview, experimental evidence, and an extended RCC as applied to Latvian and Lithuanian. Baltic Journal of Modern Computing, Vol. 7 (2019), No. 2, 224-254. https://doi.org/10.22364/bjmc.2019.7.2.02

Zwarts, J. (1997). Vectors as Relative Positions: A Compositional Semantics of Modified PPs1. Journal of semantics, 14(1), 57-86.

Zwarts, J., Winter, Y. (2000). Vector space semantics: A model-theoretic analysis of locative prepositions. Journal of logic, language and information, 9(2), 169-211. 


\section{Annexes}

ANNEX I

Most common spatial words in Latvian language - localization subgroups

\begin{tabular}{|c|c|c|c|c|c|}
\hline $\begin{array}{l}\text { Pa labi (Right } \\
\text { side) }\end{array}$ & $\begin{array}{l}\text { Zem } \\
(\text { Under })\end{array}$ & $\begin{array}{l}\text { Virs } \\
\text { (Above) }\end{array}$ & Aiz (Behind) & Iekšā (Inside) & Ap (Around) \\
\hline pa labi & zem & virs & aiz & iekšā & ap \\
\hline labajā/labā & ZEM & virsū & aizmugurē & iekš & apkārt \\
\hline $\mathrm{LAB}_{-}$ & $\begin{array}{l}\text { Zem } \\
(\text { Below }) \\
\end{array}$ & virspuse & fonā & iekšpuse & ārējā \\
\hline $\begin{array}{l}\text { Pa kreisi (Left } \\
\text { side) }\end{array}$ & apakšā & pa virsu & pēc & iekšiene & ārpusē \\
\hline pa kreisi & apakšējā & VIRS_ & ēnā & ietvaros & ārā \\
\hline kreisajā/kreisā & apakšpusē & $\begin{array}{l}\text { Augšā } \\
(U p)\end{array}$ & $\mathrm{AIZ}_{2}$ & IEKŠ_ & $\bar{A} R_{-}$ \\
\hline KREIS_ & apakšmala & augšā & \begin{tabular}{|l} 
Priekšāā (In \\
Front)
\end{tabular} & Vidū (Middle) & $\begin{array}{l}\text { Starp } \\
\text { (Between) }\end{array}$ \\
\hline \begin{tabular}{|l|} 
Blakus (Next \\
To $)$
\end{tabular} & pamatā & augšup & priekšā & vidū & starp \\
\hline blakus & saknē & augšējā & priekšplāns & pa vidu & Pār (Over) \\
\hline atstatus & apakš & uz augšu & pretī & vidusdal̦a & pār \\
\hline netālu & APAKS & no augšas & pirms & viducī & \\
\hline pie & $\begin{array}{l}\text { Lejā } \\
(\text { Down })\end{array}$ & augšpuse & priekšpusē & no vidus & \\
\hline līdzās & lejā & galvenē & pirmajā plānā & $\begin{array}{l}\text { Centrā } \\
\text { (Central) }\end{array}$ & \\
\hline nostatus & uz leju & augšdal̦a & & centrā & \\
\hline sānis & lejpus & augšmalā & & ne centrā & \\
\hline klāt & lejum & augsti & & iecentrēts & \\
\hline gar & leja & AUGS/Š & & nav iecentrēts & \\
\hline kopā & lejasdal̦ā & $\mathrm{Uz}(\mathrm{On})$ & & koncentrisks & \\
\hline nostāk & & \multirow[t]{3}{*}{$\mathrm{uz}$} & & ekscentriski & \\
\hline \multirow[t]{2}{*}{ ksēdē } & & & & centrēti & \\
\hline & & & & pa centru & \\
\hline
\end{tabular}


ANNEX II

Words used in stimuli descriptions grouped by coded categories

\begin{tabular}{|c|c|c|c|c|c|}
\hline $\begin{array}{l}\text { Darbības } \\
\text { vārdi }\end{array}$ & $\begin{array}{l}\text { Topologiski d } \\
\text { (TOPverbs) }\end{array}$ & bības v. & Prievārdi & $\begin{array}{l}\text { Apstākl̦a vāi } \\
\text { (Adverbs) }\end{array}$ & \\
\hline ir / esošs & $\begin{array}{l}\text { nav kopīgu } \\
\text { punktu }\end{array}$ & atdalījies & no & aptuveni & gandrīz \\
\hline atrodas & nesaskaras & iebrauc & ar & krietni & ne \\
\hline aiziet & saskaras & ieritinājies & pa & kādu & vienlaicīgi \\
\hline nobīdīts & šksērso & nepieskarties & par & dal̦ēji & apmēram \\
\hline novirzìts & krusto & apēdis & $\mathrm{uz}$ & nedaudz & viegli \\
\hline atdevis & pārsedz & ieskaut & pret & tieši & tā \\
\hline novietots & pārklāj & saplūst & pēc & cieši & loti \\
\hline sēž & aptver & apņem & $\begin{array}{l}\text { Saikl̦i } \\
\text { (Connectives) }\end{array}$ & uzreiz & absolūti \\
\hline tiek & ietver & sastopas & un & daudz & drīzāk \\
\hline nebūt & šksel̦ & sakrīt & vai & gluži & pašā \\
\hline iekrāsot & saķerē & nesavienoties & jeb & mazliet & \\
\hline neatrasties & savienots & apsegt & $\operatorname{ar} \overline{1}$ & pilnībā & \\
\hline iet & kombinācijā & nepārklāties & bet & samērā & \\
\hline atstāt & aizsedz & sakḷauties & $\mathrm{kā}$ & kopīgs & \\
\hline saglabāt & pieskaras & mīties & kas & ap & \\
\hline ievietot & savijies & segt & nekā & savstarpējs & \\
\hline vērsts & aizklāj & caurvijas & $\mathrm{nu}$ & relatīvi & \\
\hline dotie & nosedz & ietilpst & $\mathrm{ka}$ & attiecībā & \\
\hline atbilst & aizskar & nepiekḷauties & gan & ievērojami & \\
\hline \begin{tabular}{|l|} 
orientēts \\
\end{tabular} & piekļaujas & kontaktā & tomēr & vairāk & \\
\hline stāvēt & aizslēpts & & & brīvi & \\
\hline veido & iekl̦aut & & & & \\
\hline attālināties & paslēpts & & & & \\
\hline
\end{tabular}




\begin{tabular}{|c|c|c|c|c|c|}
\hline Virziens (Direction) & $\begin{array}{l}\text { Attālums } \\
\text { (Distance) }\end{array}$ & & & \multicolumn{2}{|c|}{ Mēri (Measures) } \\
\hline $\begin{array}{l}\text { Debesu puses } \\
(\text { Cardinal })\end{array}$ & $\begin{array}{l}\text { Attālums } \\
\text { relatīvi } \\
\text { (Relative } \\
\text { distance) }\end{array}$ & \multicolumn{2}{|c|}{ Skaiţ̦i (Numbers) } & $\begin{array}{l}\text { Mērvienības } \\
\text { (Units of } \\
\text { measurements) }\end{array}$ & $\begin{array}{l}\text { Ko mēra } \\
\text { (What is } \\
\text { measured) }\end{array}$ \\
\hline A & augstāk & $1 / 5$ & 60 & reizes & attālums \\
\hline $\mathrm{R}$ & tālāk & $1 / 4$ & 70 & grādi & atstarpe \\
\hline $\mathrm{Z}$ & tuvāk & $1 / 3$ & 90 & procenti & distance \\
\hline $\mathrm{D}$ & citur & $1 / 2$ & 135 & $\mathrm{~km}$ & stāvokis \\
\hline $\mathrm{ZA}$ & zemāk & $2 / 3$ & 225 & $\mathrm{~cm}$ & novietojums \\
\hline $\mathrm{DA}$ & netālu & $3 / 4$ & 315 & $\mathrm{~mm}$ & nobīde \\
\hline DR & pus & viens & Plkst.14.00 & $\begin{array}{l}\text { Objekts } \\
(\text { Object as } \\
\text { measure }) \\
\end{array}$ & teritorija \\
\hline ZR & attālāk & neviens & Plkst. 3 & aplis & \begin{tabular}{|l} 
atrašanās \\
vieta
\end{tabular} \\
\hline $\begin{array}{l}\text { Ģeometriski } \\
\text { (Geometric) }\end{array}$ & nākamais & 1,5 & Plkst. 4:30 & gabals & augstums \\
\hline vertikāli & viszemāk & divi & Plkst.4-5 & krustojums & pozīcija \\
\hline diagonāli & turpat & abi & Plkst.6 & pārklājums & stāvs \\
\hline virzienā & šeit & 2,5 & Plkst. 7:30 & aizsegums & \\
\hline prom & $\begin{array}{l}\text { Attāluma } \\
\text { izmērs (Size of } \\
\text { distance) }\end{array}$ & 4 & Plkst.10 & $\begin{array}{l}\text { Ģeometriski } \\
\text { (Geometric) }\end{array}$ & \\
\hline horizontāli & liels & 5 & Plkst.17.00 & diametrs & \\
\hline Slīpi & neliels & 10 & Plkst.19 & radiuss & \\
\hline sānis & paliels & 11 & vairāki & leņkis & \\
\hline taisni & mazs & 12 & $-\pi / 4$ & ass & \\
\hline paralēli & vidējs & 20 & $-3 \pi / 4$ & korpuss & \\
\hline $\mathrm{v}=(0,-2 \mathrm{~d} / 3)$ & vienāds & 30 & & garums & \\
\hline šksēersām & augošs & 45 & & lielums & \\
\hline $\mathrm{y}$ ass & tas pats & & & pulkstens & \\
\hline X projekcija & citāds & & & & \\
\hline tajā pašā līmenī & dažāds & & & & \\
\hline & tāds & & & & \\
\hline
\end{tabular}




\begin{tabular}{|c|c|c|c|c|c|}
\hline \multicolumn{2}{|c|}{ Tumšais aplis (Dark circle) } & \multirow{2}{*}{\begin{tabular}{|l}
$\begin{array}{l}\text { Abi apli (Both } \\
\text { circles) }\end{array}$ \\
Kopīga dala \\
(Common_part)
\end{tabular}} & \multicolumn{3}{|c|}{ References objekts (Reference object) } \\
\hline $\begin{array}{l}\text { Lokācija } \\
\text { (Location) }\end{array}$ & $\begin{array}{l}\text { Objekts } \\
\text { (Object) }\end{array}$ & & $\begin{array}{l}\text { Lokācija } \\
\text { (Location) }\end{array}$ & $\begin{array}{l}\text { Objekts } \\
\text { (Object) }\end{array}$ & $\begin{array}{l}\text { Objekta } \\
\text { daḷa } \\
\text { (Object } \\
\text { part) }\end{array}$ \\
\hline apakšējais & aplis & punkts & otrs & aplis & centrs \\
\hline augšējais & riņ̧̧is & mala & augšējais & riņ̧̧is & augša \\
\hline zemākais & $\begin{array}{l}\text { Objekta dal̦a } \\
\text { (Object part) }\end{array}$ & līnija & priekšējais & riṇḳa līnija & stūris \\
\hline ārējais & mala & centrs & $\begin{array}{l}\text { Izskats } \\
\text { (Appearance) }\end{array}$ & līnija & virsotne \\
\hline iekšējais & daļa & daļas & balts & lode & kvadrants \\
\hline vidējais & riņķa līnija & robežlīnijas & neiekrāsots & $\begin{array}{l}\text { Fons } \\
\text { (Background) }\end{array}$ & mala \\
\hline virsējais & līnija & virsmas & gaišs & lapa & līnija \\
\hline labais & viduspunkts & sienas & caurspīdīgs & plakne & vertikāle \\
\hline kreisais & centrs & segments & neaizpildīts & virsma & diagonāle \\
\hline brīvais & puse & pārklāšanās & $\begin{array}{l}\text { gaiši } \\
\text { iekrāsots }\end{array}$ & $\begin{array}{l}\text { Vietniekvārdi } \\
\text { (Pronouns) }\end{array}$ & daḷa \\
\hline otrais & augšmala & $\begin{array}{l}\text { Vietniekvārdi } \\
\text { (Pronouns) }\end{array}$ & bālais & tam & horizontāle \\
\hline pirmais & stūris & to & tukšs & kas & vidus \\
\hline aizmugurējais & augšdaļa & tie & tumšs & tā & segments \\
\hline $\begin{array}{l}\text { Izskats } \\
\text { (Appearance) }\end{array}$ & apakšpuse & abi & bezkrāsains & to & viduspunkts \\
\hline tumšais & iekšiene & kas & \begin{tabular}{|l} 
balti \\
iekrāsots
\end{tabular} & kurš & robeža \\
\hline iekrāsotais & $\begin{array}{l}\text { Vietniekvārdi } \\
\text { (Pronoun) }\end{array}$ & viens otram & iekrāsotais & savs & siena \\
\hline caurspīdīgs & tā & & melns & pēdējais & vieta \\
\hline necaurspīdīgais & sevī & & Izmērs (Size) & & fons \\
\hline Izmērs (Size) & to & & liels & & priekšplāns \\
\hline mazs & tam & & mazs & & lejasdaļa \\
\hline liels & tas & & & & apakšpuse \\
\hline pilns & kas & & & & līnija \\
\hline \begin{tabular}{|l|} 
vienliels \\
\end{tabular} & kurš & & & & priekšpuse \\
\hline & & & & & puse \\
\hline & & & & & virsma \\
\hline
\end{tabular}

